\title{
THE ULTRASTRUCTURE OF THE TOOTH ENAMEL OF SMALL EQUUS OF THE "TARPAN" GROUP AND THEIR POSSIBLE PHYLOGENETIC CONNECTIONS
}

\author{
VITALII DEMESHKANT ${ }^{1, *}$, LEONID REKOVETS ${ }^{1,2}$ \\ ${ }^{1}$ Institute of Biology, Faculty of Biology and Animal Breeding, Wroclaw Institute of Environmental and Life Sciences, Chełmońskiego 38c, \\ 51630 Wrocław, Poland; e-mail: vitalii.demeshkant@upwr.edu.pl. \\ ${ }^{2}$ National Museum of Natural History of the National Academy of Sciences of Ukraine, B. Khmelnytskoho 15, 01030 Kyiv, Ukraine. \\ ${ }^{*}$ corresponding author
}

Demeshkant, V., Rekovets, L. (2021): The ultrastructure of the tooth enamel of small Equus of the "tarpan" group and their possible phylogenetic connections. - Fossil Imprint, 77(1): 55-72, Praha. ISSN 2533-4050 (print), ISSN 2533-4069 (online).

\begin{abstract}
The paper presents the results of a comparative analysis of the ultrastructure of tooth enamel (incisors, premolars and molars) in representatives of morphologically (and possibly phylogenetically) similar forms of small horses. These are both extinct forms of tarpan - Equus gmelini from various sites of the early Holocene of Ukraine (Myrne, Kamiana Mohyla and Hirzhevo) and modern forms - konik polski and E. przewalskii, and European wild ass - E. hydruntinus. Morphology of prisms in different layers of tooth enamel and its relative relationships in various taxa were thoroughly described. The data obtained in the form of tables and graphs, with the appropriate statistical processing thereof, show the morphological similarity of tarpan remains from different sites, and their similarity to the konik polski and Przewalski's horse. However, the European wild ass differs significantly from the other groups studied. In equines, the radial enamel varieties (types I, II and III) have evolutionary tendencies to strengthen the first and second types of hydroxyapatite prisms, while reducing the share of the IPM matrix in the enamel structure. In turn, the enamel of the incisors is characterized by lamellar enamel of the HSB uniserial type.
\end{abstract}

Key words: horse, tooth, enamel, morphology

Received: May 3, 2021 | Accepted: November 1, 2021 | Issued: December 9, 2021

\section{Introduction}

The history and evolution of equines is relatively well studied, especially of the genus Equus. At the same time, there are always contemporary problems to discuss within taxonomy, systematics, the evolution of equines, and the genus Equus (Forsten 1988, Kuzmina 1997, Spassov and Iliev 1998, Burke et al. 2003, Schulz and Kaiser 2013, Steiner et al. 2013, Croitor 2018). The proposed schemes of taxonomy and the reconstruction of phylogenetic relationships between particular groups of horses are usually based on different morphological features, and are debatable.

This paper presents the results of the tooth enamel ultrastructure study (in incisors, premolars and molars) in various morphologically and phylogenetically similar forms, which we have combined in the current work under the non-taxonomic name of small horses, or the "tarpan" group. This includes the remains of tarpans from Holocene localities - Myrne, Kamiana Mohyla and Hirzhevo, as well as the konik polski, Przewalski's horse and, for comparison, Equus hydruntinus. The main task was to study the ultrastructure of tooth enamel as the most mechanically functional component of the digestive system, in order to determine the usefulness of this morphological feature for taxonomy, to establish phylogenetic, ecological and functional relationships, as well as the conditions for the existence of forms. At the same time, the evolutionary approach to the problem was continued, this being the basis for understanding the dynamics of environmental conditions, the history of nutrition, and determining a possible vector of changes in enamel morphology over time in the forms examined.

\section{Materials and methods}

The incisors and molars of small representatives of the genus Equus were examined under the Scanning Electron Microscope (SEM). These teeth are mainly tarpan Equus gmelini teeth from Holocene sites Myrne, Kamyana Mohyla, Hirzhevo, from the Przewalski's horse (Equus przewalskii) from the Chornobyl Exclusion Zone (Ukraine), the konik polski horse from the Roztocze National Park (Poland) and Equus hydruntinus from the beginning of the Late Pleistocene (Middle Palaeolithic) locality Kabazi 2 in the Crimea (Ukraine). The fossil horses found in the given palaeontological sites were define as Equus gmelini 
(Bibikova 1972, Bibikova and Belan 1984). The aim of this study was not to carry out a taxonomic revision of this species and the studied groups, so we just accept the above definition of the species. We also assume that Equus ferus is not synonymous with Equus gmelini. In total, 12 incisors and 22 premolars and molars were taken from the upper and lower jaws. The age assigned to individual fossil teeth was determined by conventional methods of age estimation for large ungulates (Greenfield et al. 2015, Lewis et al. 2021). To prevent a comparison bias due to ontogenetic differences in the morphology of tooth enamel, the analysis was undertaken with teeth from mature individuals of approximately the same age.

The methods of preparing the teeth for enamel microstructure study under the SEM followed the widely used standard procedures proposed by Koenigswald (1980). Horizontal sections (axial, transverse) were made parallel to the occlusal surface for molars and incisors. Vertical sections were only made in the case of the incisors. In short, their essence is that the teeth were ground on diamond plates parallel to the chewing surface and their cross-sections were polished with special pastes. The samples were then etched with $2 \%$ hydrochloric acid for 5 seconds and rinsed in water. After the test surface was spattered with gold or silver, the teeth were placed in the Zeiss ${ }^{\circledR}$ EVO LS 15 or JEOL JSM6380 LV scanning electron microscopes. Photos of the enamel structures were taken at different magnifications, then a database was created on a computer for program development. The structure of the enamel on the periphery of the tooth and on the conids was studied, and to a lesser extent, on the enamel bonds between the conids.

The enamel was analyzed in terms of structure type (I, II, III) and attendant characteristics, the width of the Interprismatic Matrix (IPM) rows and the hydroxyapatite - Prismatic Enamel (PE) rows, the mutual arrangement of the prisms among themselves and in relation to the Enamel-Dentine Junction (EDJ) and Outer-Enamel Surface (OES) boundaries, the angle of inclination of the prisms in relation to the tooth vertical, the arrangement of the prisms (crystals) into bunches and the nature of their distribution in the matrix (IPM), decussation of the enamel structures, and the manifestation of specific features, for example the appearance of structures similar to tangential enamel or Prismless External Layer of enamel (PLEX). Particular attention was paid to the morphology of the Hunter-Schreger Bands (HSB) structure of the incisor enamel. According to Wahlert and Koenigswald (1985), the enamel of the incisors is divided into two parts - PE (portio externa) and PI (portio interna). The PI section is divided into the outer OPI section and the inner IPI section. In order to better understand the enamel structures in our research we divided the incisors enamel into three parts: the outer part of PEX $(=$ PE according to Wahlert and Koenigswald 1985), the inner part of PI (= IPI according to Wahlert and Koenigswald 1985) and the middle part - HSB (= OPI according to Wahlert and Koenigswald 1985). The indices of enamel structural elements (thickness of IPM and PE prisms) were measured using ImageJ software (Schindelin et al. 2015) (Text-fig. 3,

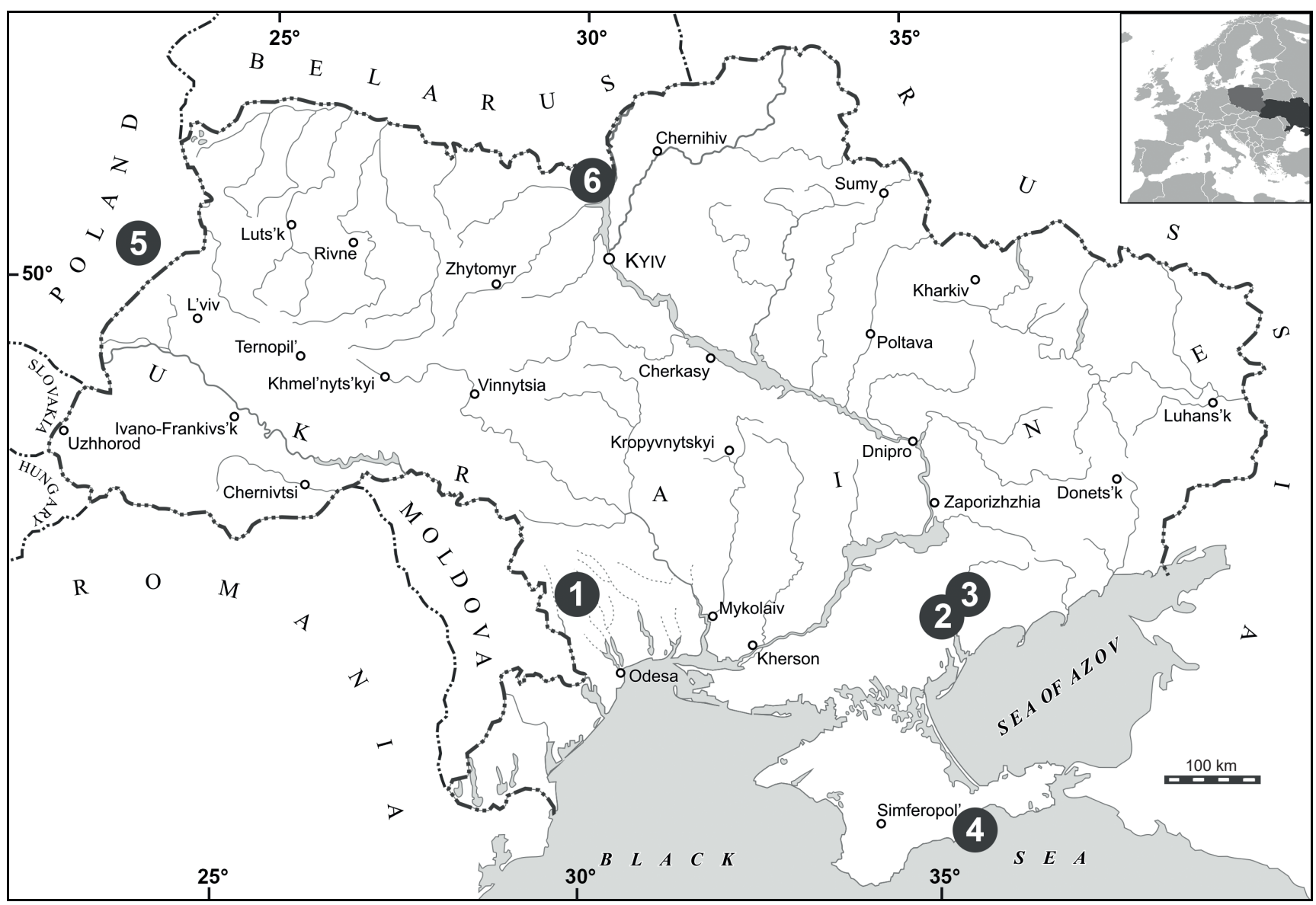

Text-fig. 1. Localities of investigated species. Black dots represent places where forms were found. 1 - Hirzhevo, 2 - Myrne, 3 - Kamiana Mohyla, 4 - Kabazi 2, 5 - Roztocze National Park, 6 - Chornobyl Exclusion Zone. 
Tab. 1). The statistical analysis was performed using the Statistica 13 program. Statistical significance was set at $\mathrm{p} \leq 0.05$ for each variable.

The initial conclusions have a methodological character. From the subject literature (Koenigswald 1980, Wahlert and Koenigswald 1985, Kalthoff 2000), it is known that enamel is a fairly hard and morphologically relatively stable structure, capable of responding to a large functional load. It has been proven that in ontogenesis of horses at the age of 7-8 years, its structure stabilizes, although it is subject to abrasion due to hypsodonty. Our research supports these claims and shows that the enamel structure of both upper and lower molars is essentially similar. The existing differences in this structure are described in the text as characterizing the variability of enamel. These differences are sometimes not of taxonomic importance but may reflect adaptation and nature of the feed. Taking these suggestions into account, the text presents the characteristics of tooth enamel separately for incisors and together for premolars and molars. In the expressions "molars" or "cheek teeth" we include what are commonly understood as premolars and molars.

The text contains a brief general description of the species studied, and for extinct forms also brief information about the localities (Kabazi 2, Myrne, Kamiana Mohyla, Hirzhevo; Text-fig. 1). A detailed description of the tooth enamel morphology, comparative data analysis, and conclusions constitute the main results from our research.

$\begin{array}{ll}\text { Abbreviations } \\ \text { EDJ } & \text { enamel-dentine junction } \\ \text { HSB } & \text { Hunter-Schreger bands } \\ \text { IPM } & \text { interprismatic matrix } \\ \text { OES } & \text { outer-enamel surface } \\ \text { PE } & \text { prismatic enamel } \\ \text { PEX } & \text { portio externa } \\ \text { PI } & \text { portio interna } \\ \text { PLEX } & \text { prismless external layer of enamel } \\ \text { TZ } & \text { transition zone }\end{array}$

\section{Brief description of the forms studied and their localities}

\section{Tarpan (Equus gmelini Antonius, 1912)}

In nature, this species was widely distributed across the steppes of Europe and Asia, from the early Holocene to the end of the $19^{\text {th }}$ century. The history of the species, its taxonomic status and systematic position are still the subject of scientific discussion (Gromova 1949, Bibikova 1972, Bibikova and Belan 1979, 1981, 1984, Kosintsev 2015, Croitor 2018).

The position of many authors on the division of the species under the general name of "tarpan" into separate taxonomic groups, possibly with the rank of subspecies, is generally accepted, and at the same time somewhat debatable: steppe - Equus gmelini gmelini AnTonius, 1912 and forest - Equus caballus var. sylvatica according to Vetulani 1928, (= Equus gmelini sylvaticus according to Kuzmina 1997 = Equus caballus gmelini ANTONIUs forma silvatica VETULANI according to Jaworska et al. 2020) From these taxonomic groups, the conclusion is clear - today the systematics, taxonomy and nomenclature of abovementioned representatives of the genus Equus is relatively ambiguous and debatable (Kuzmina 1997, Kosintsev and Bachura 2013, Seetah et al. 2016, Cucchi et al. 2017, Croitor 2018). In Southeast Europe, the species Equus gmelini is known from the Holocene, apparently as a migrant from Asia.

In our research, we did not deal with the taxonomy and systematics of tarpans, but assumed that Equus gmelini is an extinct species (Gromova 1949). It includes two ecological types: steppe, Equus gmelini gmelini, and forest, Equus gmelini sylvaticus. For formal reasons, these taxa can be considered at the subspecies level. There was an assumption that the konik polski (Polish konik), a Polish native horse breed (Equus caballus), is closely related phylogenetically to the forest type of tarpan (Gladenko 1976). However, later studies did not confirm this theses. Konik polski shows a great resemblance to the extinct wild tarpan, but it is not genetically the same breed (Fornal et al. 2020). Our goal was to study the ultrastructure of the enamel of their teeth, conduct a comparative analysis of the data obtained with species close to the tarpan, and formulate appropriate conclusions.

The studies of Gromova (1949), Bibikova (1972) and later Belan (Bibikova and Belan 1981, 1984) revealed the distinctive features of the tarpan species, Equus gmelini, based on the morphology of the skull, teeth and bones of the postcranial skeleton. The authors noted that this species was smaller than the others, with relatively shorter maxillary teeth, an elongated $\mathrm{m} 3$ talonid, a shortened protocone, and an enlarged distal part of the first phalanx. This sets it apart from other related forms - Equus caballus LinNAEus, 1758, Equus latipes Gromova, 1949 and Equus scythicus RAdulescu et SAMSON, 1962.

A more complete description of tarpan osteomorphology was provided by Roman Croitor (Croitor 2018). He noted differences in the proportions of the skull, in particular the first and second phalanges (phalanxes), in individual elements of the dentition. The horses from Botai culture in Kazakhstan are related in origin with Equus przewalskii (Orlando et al. 2008). It is supposed that E. przewalskii is a feral form of the domesticated E. caballus derived from Botai (Levine 1999, Gaunitz et al. 2018). But this opinion was recently questioned by Taylor and Barrón-Ortiz (2021), who suggest that Botai horses represent rather wild than domesticated form.

The species tarpan, Equus gmelini AnTonius, 1912, inhabited the territory of south-eastern Europe, was adapted to the barren conditions of the steppe and led a herd lifestyle (Bibikova and Belan 1981, 1984, Conti et al. 2010, Kosintsev and Bachura 2013, Kosintsev 2015). As a steppe form of the southern part of Europe (Italy, Ukraine), its main feed was halophytes, which are characterized by high osmotic pressure in cells and the presence of phytoliths (Burke et al. 2003). The last of these is an important indicator of the process of biting and chewing food, and thus the process of abrasion of teeth and enamel (Erickson 2014). Bibikova and Belan $(1981,1984)$ in their works justify the osteological differences of tarpan from the comparative forms of wild small horses, and suggest the history of their origin as 
a separate phylogenetic branch of equines in the Pleistocene of Europe. In this region, cabbaloid horses are known from the Middle Pleistocene (Galerian) and are well represented by Late Pleistocene or Holocene forms such as Equus ferus germanicus, Equus ferus gallicus and Equus ferus gmelini (Conti et al. 2010). According to these authors, the tarpan was domesticated during the eneolite, and is known as Equus caballus.

In the Holocene sites Myrne, Kamiana Mohyla and Hirzhevo, osteological remains of tarpan Equus gmelini were not particularly numerous (in total 75 bones are known), but were reliably defined. This is evidenced by data from Bibikova and Belan $(1981,1984)$, who show that at that time, there were no Equus latipes (extinct) and no domesticated Equus yet, which also proves the authenticity of the remains in favor of the distinctiveness of the tarpan species. In addition, the aforementioned authors provided diagnostic differences between tarpan and similar forms. DNA analysis of equines and the related process of their domestication provide variable and perhaps questionable data on phylogeographic content (Jansen et al. 2002, Viltsrup et al. 2013). A short description is given of the Holocene Ukrainian sites in which the remains of the tarpan species were found.

\section{Myrne locality}

This is known primarily as a monument of archaeological culture of the Stone Age in the south-western region of Ukraine (Kiliya district, Odesa region). It belongs to the Late Mesolithic (Grzebenik's archaeological culture), which is 8,500-9,000 years old (Sapoznikov and Sapoznikova 2011). The list of fauna species at this site includes aurochs, tarpan, European wild ass, saiga antelope, red deer, wild boar, wolf, fox, European badger, hare and marbled polecat, all with dominance of the steppe representatives (Bibikova and Belan 1981).

\section{Kamiana Mohyla locality}

This is known as a natural and historical multilayered monument of Ukraine from different epochs of the Holocene (Melitopol district, Zaporizhia region of Ukraine). An unusual accumulation of large stone slabs and hard sandstones (sediments of the Sarmatian Basin) with a height of up to $12 \mathrm{~m}$ covers almost 3 hectares of land near the Molochna River. This proved a relatively convenient place in steppe Ukraine for periodic human settlement starting in the Late Paleolithic. On the rocks of the caves and grottoes of this tomb, paintings and drawings (petroglyphs) were made of various animals, including tarpans, and the settlers here contributed to the accumulation of large bones, mainly large mammals. Horse osteological materials have been classified as being tarpan (Equus gmelini). The remains of species such as horses, deer and antelopes are also known in the area (Sapoznikov and Sapoznikova 2011).

\section{Hirzhevo locality}

This locality is in the Velyko-Mykhailivskyi district of Odesa region of Ukraine, and is characteristic of the stage of natural and societal development of the first half of the Holocene, the early Neolithic, which is 7,000 years old - and the emergence of the Samchyn culture (Sapoznikov and Sapoznikova 2011). According to the data collected by Bibikova and Belan (Bibikova and Belan 1979, 1981, 1984) in Hirzhevo, the remains of species such as auroch, tarpan and the European wild ass are known, while neither the presence of domesticated animals nor the morphological changes found in the process of the domestication of wild fauna were detected. This means that the horse remains genuinely do belong to the tarpan Equus gmelini.

\section{Konik polski (Equus caballus LinnaEus, 1758)}

Known in the literature as a tarpan hybrid with the domesticated but feral horse Equus caballus, with the hybridization happening back in the $19^{\text {th }}$ century (Vetulani 1928, Siemieniuch and Jaworski 2019). The history of this form is quite rich in its variety of arguments and curiosities, and is well described in publications and in the collection of scientific works devoted to the $70^{\text {th }}$ anniversary of breeding and keeping of konik polski in Popielno, Poland in 2019. Ecologically, this form is related to the forest form of tarpan and is most likely similar to the previous form from the Białowieża Primeval Forest (Cieslak et al. 2017, Kaminski et al. 2017, Jaworska et al. 2020). In terms of its existence, it differs from the steppe form of tarpan in the southern part of Eastern Europe (Pasicka 2013). Data from molecular genetic analysis have led scientists to believe that they are ecologically and phylogenetically closely related varieties of small horses (Frątczak et al. 2020).

\section{Przewalski's horse (Equus przewalskii Polyakov, 1881)}

The history of the species description and its characteristics is relatively well known from a number of publications (Vilstrup et al. 2013, Seetah et al. 2016). As for the taxonomic status of the species and its systematic position in the equine system, the question is still open. The latest data on this topic are contained in the specialized collection of scientific works of the reserve Askania Nova (Journal of the Biosphere Reserve Askania Nova 2019). There are three main views on its taxonomic status: as a separate species Equus przewalskii, as a subspecies of Equus ferus, E. f. przewalskii and as a subspecies of the domestic horse Equus caballus przewalskii. Recent views, based on DNA analysis, suggest that Przewalski's horses were wild domesticated horses from eastern Kazakhstan, which were an integral part of the Botai culture more than 5,000 years ago (Kuzmina 1997, Orlando et al. 2006, 2008, Kositsev 2013). Genetic and molecular data suggest that this species is close to Equus gmelini and Equus caballus (Orlando et al. 2006, 2009, Vilstrup et al. 2013, Seetah et al. 2016, Cucchi et al. 2017, Kvist and Niskanen 2020). Several studies have been devoted to research on the ultrastructure of tooth enamel of this taxon (Demeshkant 2019, Slivinska et al. 2019), which are complemented by the comparative data of the current study.

\section{European wild ass (Equus hydruntinus RegaLIA, 1907)}

Studied material originates from the locality Kabazi 2 (Crimea, Ukraine), Late Pleistocene. The uniqueness of the Kabazi 2 site lies in the fact that from the beginning of the Late Pleistocene (OIS/MIS 5e) onwards, confirmed 
Neanderthal artifacts, and later artifacts of ancient humans and the remains of fauna from 55 horizons in situ have all been discovered, suggesting the continuous presence of people in this place. The locality is well researched as a Paleolithic monument, and has a comprehensive faunistic character (Chabai et al. 2004). There is strong evidence for Middle Palaeolithic occupation at Kabazi 2. According to Markova (2005) it started in Eemian. Spindler et al. (2021) also supported Middle Paleolithic age for the locality. But there is evidence of the occupation of Middle Pleistocene age. At various stages of the manifestation of the temperature dynamics of the Late Pleistocene, the dominant species were Equus hydruntinus, Microtus obscurus, Arvicola amphibius and Eolagurus luteus, which generally testified to the existence of dry steppe spaces. The enamel of the molars and incisors of a European wild ass from this lineage was also examined to provide a point of comparison with the data with other Equidae groups.

The representative of wild horses - the European wild ass (Equus hydruntinus) lived in the second half of the Pleistocene in southern Europe, and to the east as far as Iran (Burke et al. 2003). Morphologically, it was similar to the small horses of the "tarpan" group, and phylogenetically it was related to the kulan Equus hemionus PALLAS, 1775, despite the fact that their subgenus affiliation is different - Asinus and Hemionus (Orlando et al. 2006, 2008, Bennett et al. 2017). This group of small horses was adapted to the dry steppe conditions and the available feed, which they ate by actively grinding it. Relevant features characterize its evolutionary level, and the adaptations influenced the morphological similarities in the structure of teeth and enamel of these forms.

\section{Results}

\section{The morphology (ultrastructure) of the enamel of the molars}

As we noted earlier in the Materials and methods chapter, the structure of the enamel of the upper and lower molars, which are functionally adapted to chew feed, is similar, and differs from the structure of the incisors, which perform the function of biting and cutting food. This confirms the principles of evolutionary morphology with the interdependent relationship of morphology, function, and environment as a result of the course of the process of evolution, and manifestation of the overall functional system (Koenigswald et al. 1993, Martin 2000). The tooth enamel was examined in terms of its typification (types I, II, III), the arrangement of structural elements, and the search for morphological and functional differences in comparable groups at taxonomic levels (Tab. 1).

\section{Tooth enamel description (types I-III)}

Research on the morphology of the enamel of horses' teeth was carried out, with due consideration taken of the previously distinguished types of enamel structure. According to Koenigswald, three basic types of enamel are characteristic for mammalian teeth: radial, tangential and lamellar, along with their possible variations (Koenigswald 1980). For horse teeth, the most primitive enamel is the most common, this being radial enamel, for which different types of structure have been distinguished. This was first attempted by Boyde (1964) and completed by Kilic in 1997 (Kilic et al. 1997a, b). The basic characteristics of the three types of radial enamel structure in horses are presented below.

The first type (I) of structure is always found closer to the enamel-dentine junction (EDJ) boundary (Text-fig. 4b). It covers up to $40 \%$ of the area of the total enamel band width and is built of parallel and sequentially arranged rows (strips) of prisms (P) and matrix structures (IPM). The prisms are usually grouped in lens-like bunches (single prisms are rarely found) and are always slightly tilted towards the EDJ. IPM rows have a poorly expressed (or hidden) crystalline structure, and demonstrate a possible dichotomy (branching) towards the outer enamel surface (OES) boundary, as well as a constantly directed morphology towards thinning of the band. This band, next to the OES boundary, is often not visible. Closer to the EDJ boundaries, the PE and IPM bands may be of different thicknesses. For instance, extinct forms Equus latipes, E. hydruntinus and E. gmelini (found in the Myrne locality) have thicker IPM rows (avg. $1.62 \mu \mathrm{m}$ ) than PE rows $(1.17 \mu \mathrm{m})$. In some species (E. przewalskii) they are almost of equal thickness $(1.35 \mu \mathrm{m})$, and in modern domestic horses (E. caballus) the IPM rows are much thicker than the prisms.

The second type (II) of structure is located next to the OES boundary (Text-fig. 4c), and occupies $40-45 \%$ of the overall enamel row width. They are also built of roughly parallel but consecutively arranged prism row (P) and IPM matrix structures. The prisms are grouped into elongated, hoof-like, rarely round (in cross-section) bundles and inclined (more like type I) towards the OES boundaries. IPM rows are very thin (avg. $0.93 \mu \mathrm{m}$ ), and next to the border they may fade out or not be visible. Prism rows (P) are very thick (avg. $2.12 \mu \mathrm{m}$ ), and it is this that clearly distinguishes the first and second types of structure. The described form in the cross-section of prism packages is common to small horses of the "tarpan" group, and for horses of the "caballus" group, they are usually very elongated.

The third type (III) of structure is at the edges of the EDJ boundary (between the first type and the dentin) (Textfig. 6f). Ontogenetically, this type is closely related to the dentin ameloblasts and the enamel production process. This type occupies $5-8 \%$ of the total area of the enamel row width. The prisms $(\mathrm{P})$ are grouped into round or elongated and thicker bundles (avg. $2.33 \mu \mathrm{m}$ ). With thin structures of IPM matrix (avg. $1.0 \mu \mathrm{m}$ ), they do not form precise rows, but are arranged somewhat chaotically. This structure markedly distinguishes this type from the others.

The border between the different types of enamel structure is not clear, and is of a transitional nature (Textfig. 4a). This is especially noticeable between the first and second types. In this work, this border is referred to as the transition zone (TZ), and always has a wave-like structure of the PE and IPM rows, often with decussations (Text-fig. 7e), which is most common in small horses of the "tarpan" group (who possess a very weak wave-like structure in the "caballus" group). In the transitional zone, a progressive or more rapid process of change to the thickness of the PE and IPM rows can be observed. We emphasize that this is not a separate type of enamel structure. 
Table 1. IPM and PE thickness measurements $(\mu \mathrm{m})$ of various types (I-III) of tooth enamel in the representative of the genus Equus.

\begin{tabular}{|c|c|c|c|c|c|c|c|}
\hline Species & Locality & I IPM & I PE & II IPM & II PE & III IPM & III PE \\
\hline E. gmelini & Myrne & & & & & & \\
\hline average & & 1.91 & 0.96 & 0.88 & 1.33 & 1.31 & 3.17 \\
\hline $\max$ & & 2.58 & 1.50 & 1.15 & 1.71 & 1.89 & 3.57 \\
\hline $\min$ & & 1.06 & 0.71 & 0.59 & 1.02 & 0.96 & 2.58 \\
\hline $\mathrm{sd}$ & & 0.47 & 0.19 & 0.15 & 0.18 & 0.27 & 0.37 \\
\hline $\mathrm{CV}$ & & 0.25 & 0.19 & 0.17 & 0.14 & 0.20 & 0.12 \\
\hline E. gmelini & Kamiana Mohyla & & & & & & \\
\hline average & & 1.61 & 1.21 & 0.98 & 3.27 & 1.17 & 2.41 \\
\hline $\max$ & & 1.94 & 1.58 & 1.56 & 4.66 & 1.42 & 2.81 \\
\hline $\min$ & & 1.32 & 0.96 & 0.67 & 1.26 & 0.86 & 1.83 \\
\hline $\mathrm{sd}$ & & 0.19 & 0.15 & 0.26 & 1.02 & 0.18 & 0.26 \\
\hline $\mathrm{CV}$ & & 0.12 & 0.13 & 0.27 & 0.31 & 0.15 & 0.11 \\
\hline E. gmelini & Hirzhevo & & & & & & \\
\hline average & & 1.31 & 1.38 & 0.85 & 1.94 & 0.88 & 1.99 \\
\hline $\max$ & & 1.92 & 1.94 & 1.12 & 2.33 & 1.32 & 2.76 \\
\hline $\min$ & & 0.88 & 0.91 & 0.52 & 1.37 & 0.61 & 1.45 \\
\hline sd & & 0.31 & 0.26 & 0.16 & 0.30 & 0.24 & 0.47 \\
\hline $\mathrm{CV}$ & & 0.24 & 0.19 & 0.19 & 0.16 & 0.27 & 0.24 \\
\hline E. caballus & Roztocze NP & & & & & & \\
\hline average & & 1.65 & 1.33 & 1.16 & 2.67 & 1.11 & 3.03 \\
\hline $\max$ & & 2.50 & 1.96 & 1.40 & 3.54 & 1.52 & 4.12 \\
\hline $\min$ & & 1.15 & 0.90 & 0.74 & 1.99 & 0.67 & 1.82 \\
\hline $\mathrm{sd}$ & & 0.32 & 0.26 & 0.17 & 0.46 & 0.25 & 0.84 \\
\hline $\mathrm{CV}$ & & 0.19 & 0.20 & 0.15 & 0.17 & 0.22 & 0.28 \\
\hline E. przewalskii & CEZ & & & & & & \\
\hline average & & 1.35 & 1.35 & 1.20 & 1.20 & 1.18 & 2.06 \\
\hline $\max$ & & 2.15 & 1.80 & 1.82 & 2.58 & 1.42 & 2.22 \\
\hline $\min$ & & 1.04 & 0.95 & 0.81 & 1.62 & 0.83 & 1.90 \\
\hline $\mathrm{sd}$ & & 0.28 & 0.26 & 0.28 & 0.26 & 0.23 & 0.13 \\
\hline $\mathrm{CV}$ & & 0.21 & 0.19 & 0.23 & 0.21 & 0.20 & 0.06 \\
\hline E. hydruntinus & Kabazi 2 & & & & & & \\
\hline average & & 1.93 & 0.78 & 0.59 & 2.24 & 0.87 & 1.31 \\
\hline $\max$ & & 2.58 & 1.89 & 0.80 & 2.87 & 1.12 & 2.69 \\
\hline $\min$ & & 1.48 & 0.39 & 0.42 & 1.75 & 0.58 & 0.81 \\
\hline sd & & 0.27 & 0.33 & 0.12 & 0.29 & 0.17 & 0.56 \\
\hline $\mathrm{CV}$ & & 0.14 & 0.42 & 0.19 & 0.13 & 0.19 & 0.43 \\
\hline
\end{tabular}

The HSB-type of enamel is characteristic for the incisors and canine teeth of horses. In essence, it is a multi-series lamellar enamel (Koenigswald 1980) and has a different character of entanglement of prisms and consistent arrangement in the vertical space of the tooth (diazone, parazone), including the root (Text-figs 10a, 13a). This is a characteristic of the strengthened structure of the enamel, and relates to its functionality - chewing food together with phytoliths and sand crystals.

The morphology of the enamel structure was assessed by the morphometric indicators which are presented in Table 1.

A brief description of the morphology of tarpan enamel from various sites, as well as the enamel structure of other species, is presented below. Results of the quantitative analyses of particular studied variables are presented in Table 1, as well as graphically with the characteristics of the range of variability of IPM and PE indicators (Text-fig. 2) and their directed evolutionary variability (Text-fig. 3) in different types of enamel (I-III) of the studied groups of genus Equus.

\section{Equus gmelini, tarpan, Myrne locality, M1-2}

Behind the structure, the enamel is mainly of the first type, for which the characteristic parallel rows of PE are hydroxyapatite prisms and the IPM matrix (Text-fig. 4a, b). This enamel structure is preserved on practically all conids and on the circumference of the chewing teeth. Regularly (for example on a paracone) in the center of the enamel between the boundaries of EDJ and OES, a narrow band of weaving structures is observed (transitional TZ zone), which are poorly filled with prisms (Text-fig. 4a). 

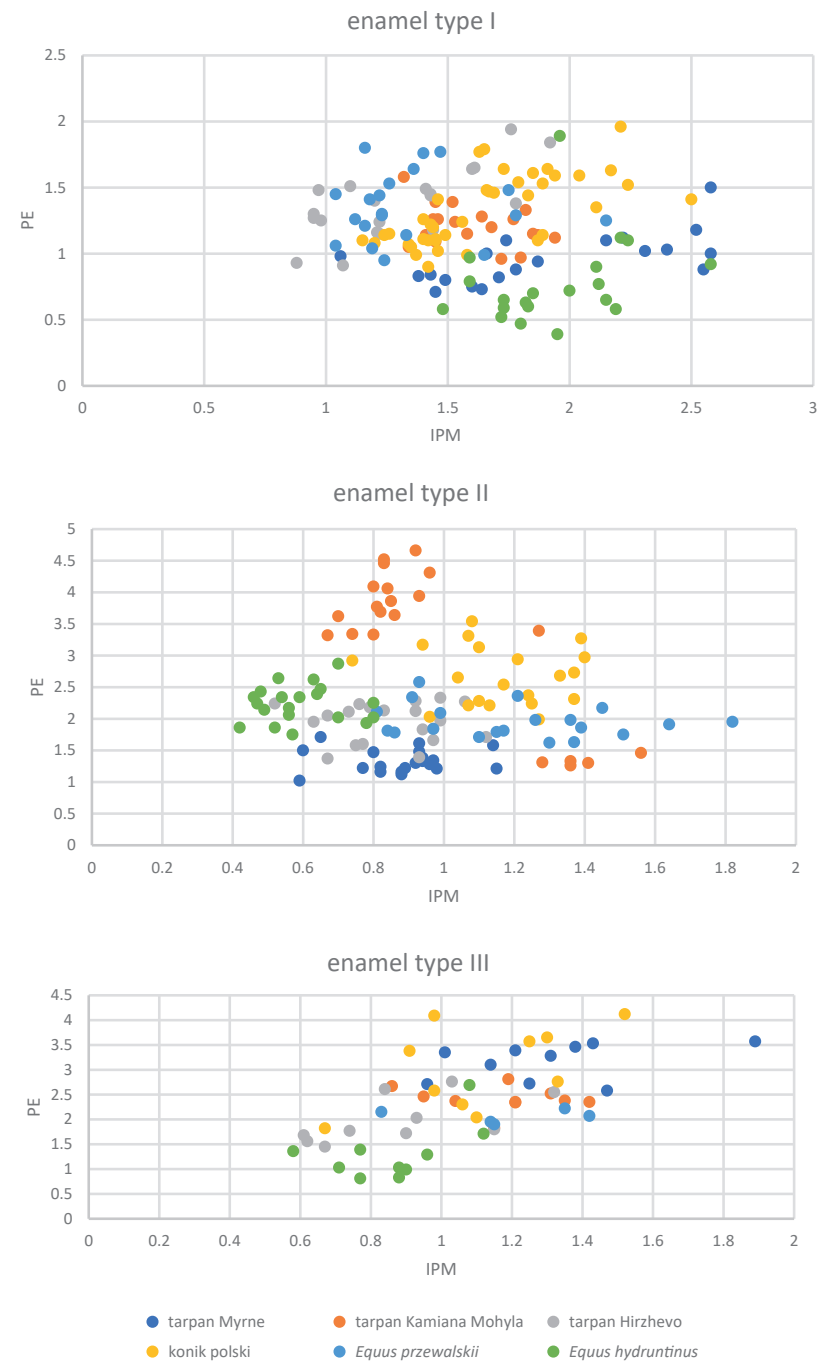

Text-fig. 2. Measurements $(\mu \mathrm{m})$ of the width of IPM and PE prisms of various types of enamel in representatives of Equidae from the "tarpan" group.

The type I enamel layer near the EDJ border is composed of rigidly parallel rows of the IPM matrix of fine crystalline structure, and rows of lenticular bunches of PE hydroxyapatite prisms of fine crystalline structure (Textfig. $4 a, b)$. The thickness of the IPM rows is two times greater than the thickness of the prism rows (Tab. 1). In some cases, the prisms of hydroxyapatite are not arranged in bunches, but comprise an uninterrupted string of tightly
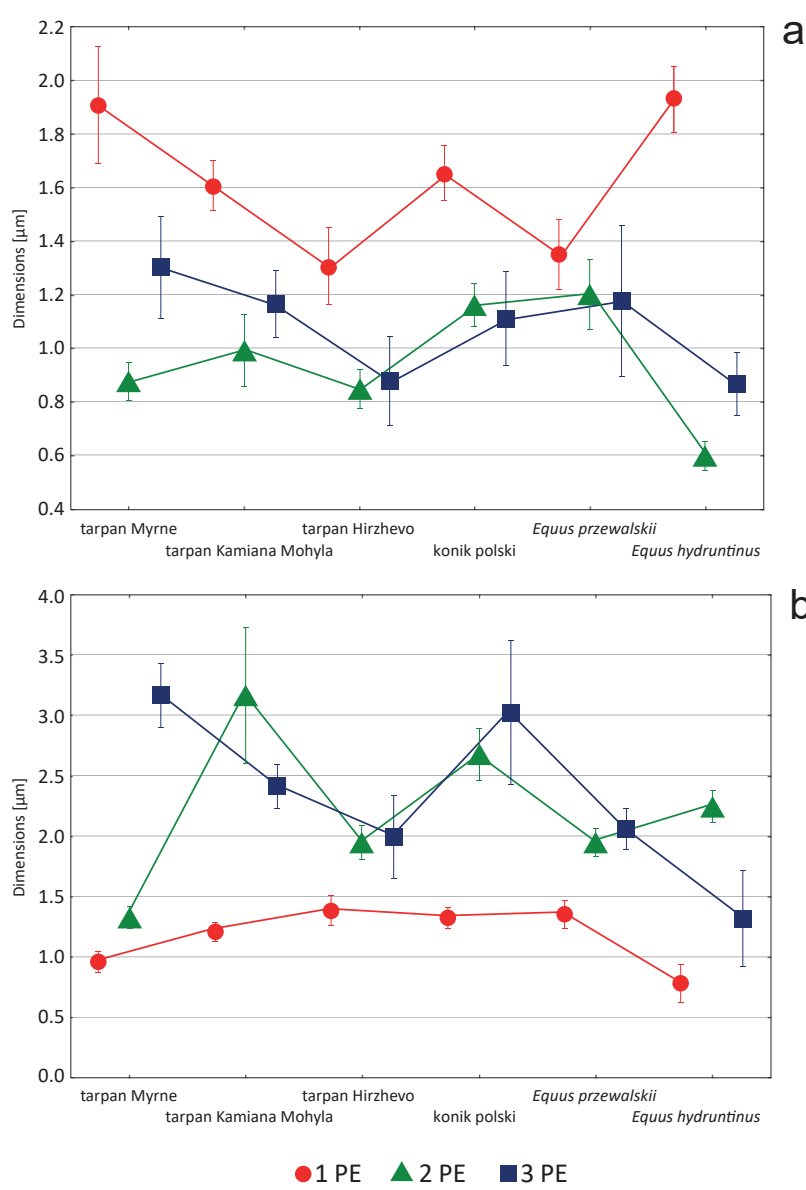

Text-fig. 3. Tendency of changes in IPM and PE width indicators in different types of enamel of the Equidae species of the "tarpan" group. I-III - types of enamel. a: IPM; b: PE.

arranged individual prisms inclined towards the OES limits. In the middle of the enamel band there is a transitional zone (TZ) between type I and type II enamel, which demonstrates the tendency to reduce the thickness of the IPM rows and increase the thickness of the hydroxyapatite (PE) prisms. These TZ zone prisms transition to type II enamel towards the OES boundary. They are characterized by an almost two-fold increase in the PE prism bundle row thickness against the background of a decrease in the IPM structure row thickness. The prisms of the second type of enamel fold into elongated bunches, horseshoe-shaped, fine-crystalline, inclined towards the OES border (Text-fig. 4c). The third type of enamel next to the EDJ border is very poorly
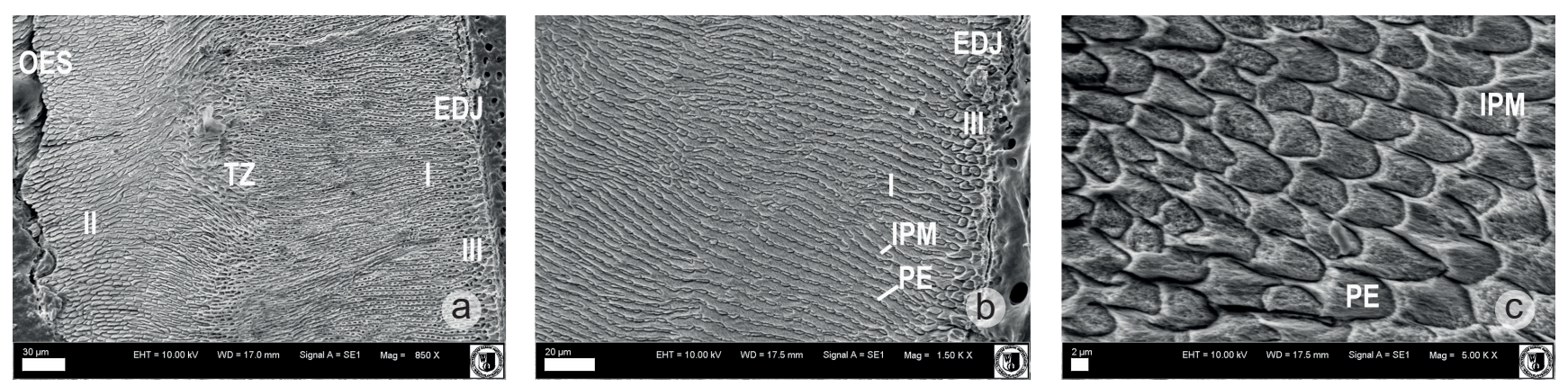

Text-fig. 4. Enamel ultrastructure of M1-2, Equus gmelini (Myrne). a: enamel row, scale bar = $30 \mu \mathrm{m}$; b: type I and III, scale bar $=20 \mu \mathrm{m}$; c: type II near OES border, scale bar $=2 \mu \mathrm{m}$. 

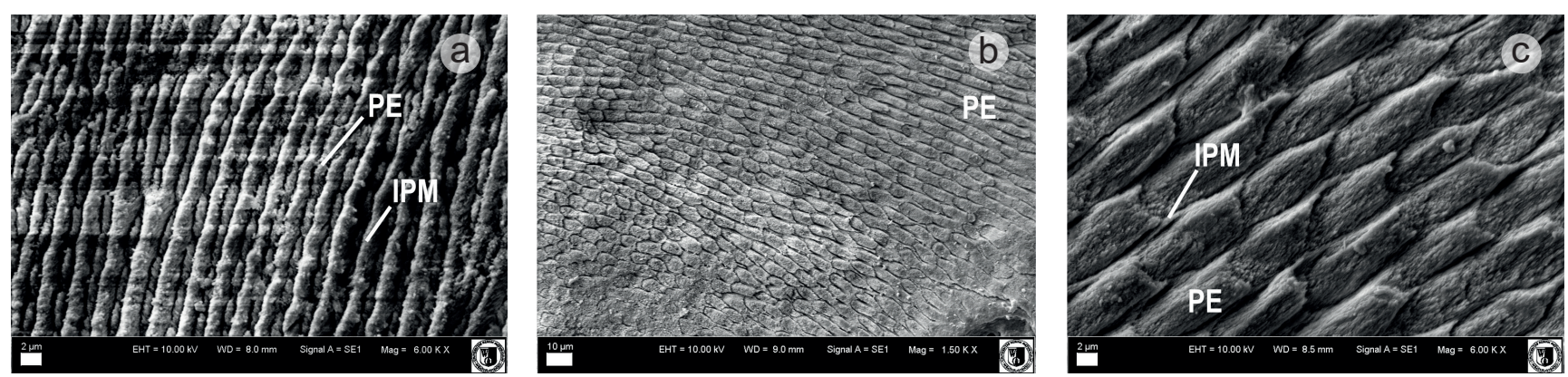

Text-fig. 5. Enamel ultrastructure of m1-2, Equus gmelini (Kamiana Mohyla). a: type I, scale bar = $2 \mu \mathrm{m}$; b: type II, scale bar $=10 \mu \mathrm{m}$; c: type II near the OES border, scale bar $=2 \mu \mathrm{m}$.

presented (Text-fig. 3b). The lower teeth of this form have a similar enamel structure. Tarpans from Myrne, compared to other forms, have the thickest IPM and the thinnest PE in enamel type I, which brings them closer to E. hydruntinus (Tab. 1, Text-figs 3, 4).

\section{Equus gmelini, tarpan, Kamiana Mohyla locality, m1-2}

The enamel has a monotype structure (3 types) with respect to other comparable forms of the species. IPM structures of the first type are thicker than PE hydroxyapatite prism tufts, which are lenticular in shape and composed of fine crystals (Tab. 1, Text-fig. 5a) In the transition zone, TZ, the wave-like structure of the prisms is hardly noticeable.

Rows of the first type of enamel transition quite smoothly and gradually to the second type of enamel, which is most pronounced next to the OES border. The enamel type II has strongly developed and thick bundles of PE prisms separated by rather poorly observed IPM structures (Text-fig. 5b). The prism bundles of the second type in cross-section resemble the shape of an elongated hoof (Text-fig. 5c), which distinguishes them from other comparable forms, and they are tilted at a greater angle (almost $30^{\circ}$ ) to the chewing surface of the tooth. The third type of enamel next to the EDJ border is very weak.

Generally speaking, the enamel of the species from Kamiana Mohyla is positioned similarly to that of the Hirzhevo site, distinguishing it from the remains from Myrne by the lack of wave-like enamel structures in the TZ zone, and with almost the same thickness of IPM rows and PE prisms.

\section{Equus gmelini, tarpan, Hirzhevo locality, M2}

The radial enamel of the Hirzhevo species also has a typical structure and can be divided into 3 types (Kilic et al. 1997a). The first type is almost $80 \%$ of the thickness of the total enamel around the perimeter of the tooth. This type of enamel has even and parallel rows of IPM and bundles of PE prisms (Text-fig. 6a). The enamel of the first type closer to the EDJ limits has a rectilinear structure in its arrangement of the IPM and PE prisms, while their thickness is practically the same (Tab. 1, Text-figs 3, 4). The prisms are arranged in an elongated tuft shape that is slightly inclined towards
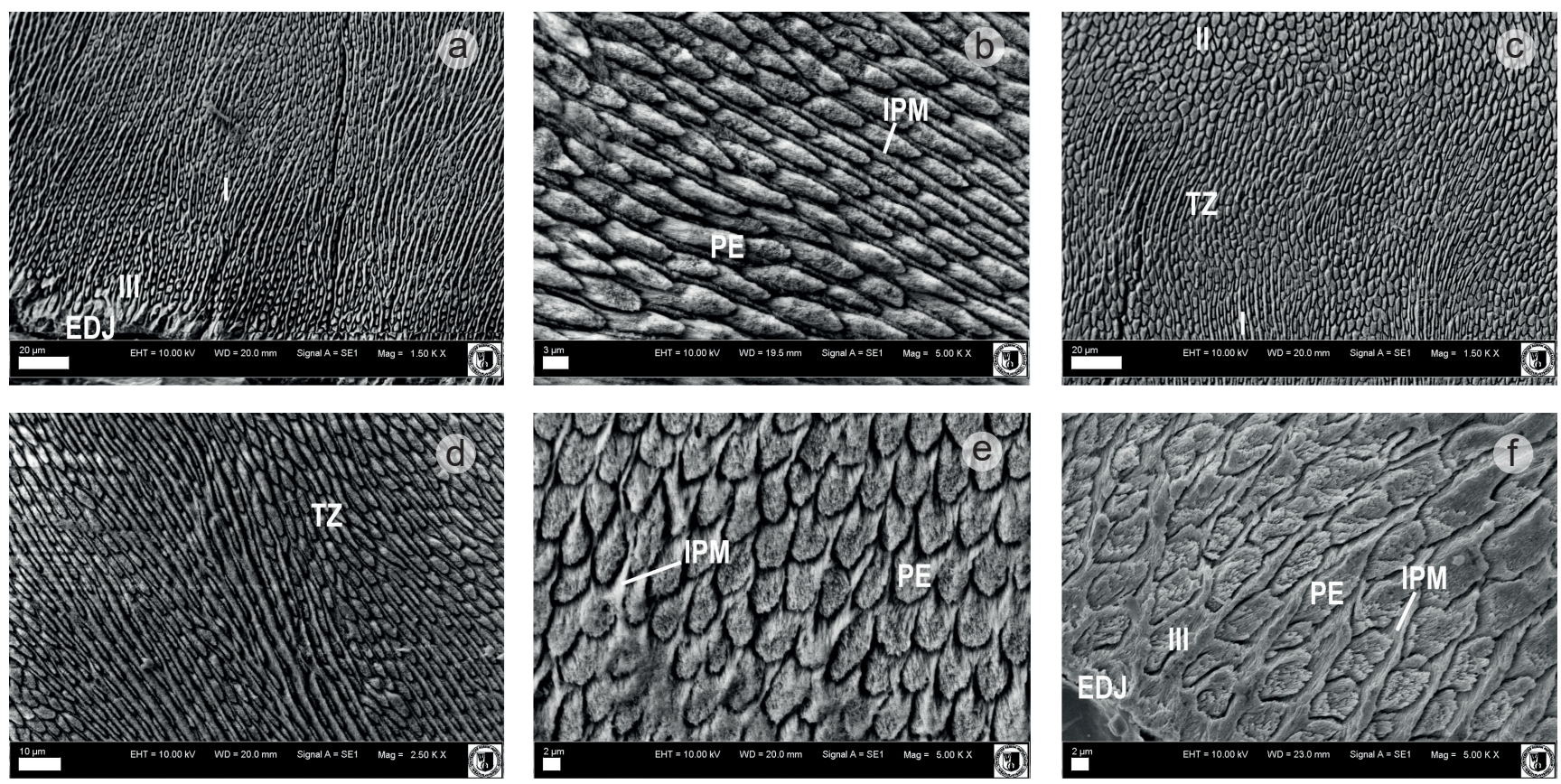

Text-fig. 6. Enamel ultrastructure of M2, Equus gmelini (Hirzhevo). a: type I and III, scale bar = $20 \mu \mathrm{m}$; b: IPM and PE first type prisms, scale bar $=3 \mu \mathrm{m}$; c, d: wavy/decussated enamel of TZ, scale bar $=20$ and $10 \mu \mathrm{m}$ respectively; e: type II near OES border, scale bar $=2 \mu \mathrm{m}$; f: type III, scale bar $=2 \mu \mathrm{m}$. 

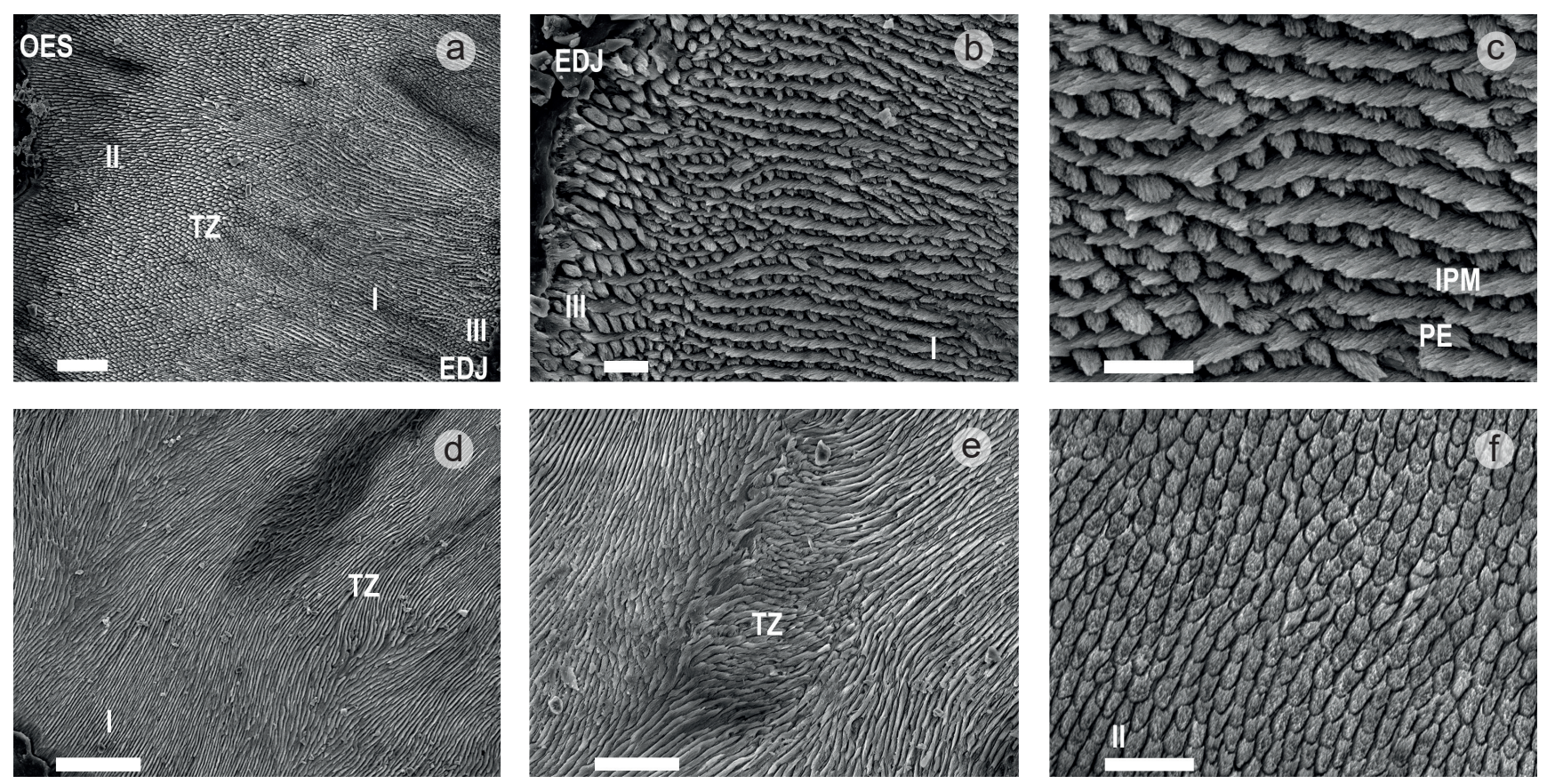

Text-fig. 7. Enamel ultrastructure of P3, Equus caballus (konik polski). a: enamel row, scale bar $=50 \mu \mathrm{m}$; b: type I and III, scale bar $=\mathbf{5 0} \mu \mathrm{m}$; c: type I, scale bar $=10 \mu \mathrm{m}$; d, e: wavy enamel of $\mathrm{TZ}$ with decussations, scale bar $=100$ and $50 \mu \mathrm{m}$ respectively; f: type II near OES, scale bar $=10 \mu \mathrm{m}$.

the EDJ boundary, which is particularly well observed in the protocone (Text-fig. 6a). In the transition zone (TZ), the prisms do not create decussations, and are arranged in a slightly wave-like structure displaying the transition from the first type of enamel to the second type (Text-fig. 6c, d). Immediately next to the EDJ border, a weak layer (about $5 \%$ of the total enamel thickness) of type III enamel is observed. This is characterized by relatively large, tilted bunches of prisms (PE) separated by very thin (weak) IPM structures (Text-fig. 6a, f).

The second type of enamel towards the OES boundary is characterized by a decrease in the thickness of the IPM structures (to $0.85 \mu \mathrm{m}$ ), which are rarely noticeable on the abrasion surface, and an increase in the thickness of PE prism bundles (to $1.94 \mu \mathrm{m}$ ) (Text-fig. 6b), which take a horseshoelike shape (Text-fig. 6e). The angle of their inclination to the chewing surface of the teeth is almost $35^{\circ}$.

In short, it can be stated that the structure of the enamel of chewing teeth in the tarpan species from different Holocene sites over the centuries is very similar. We distinguish the presence of three types of enamel: the first and third are closer to each other and next to the EDJ border; the second is next to the OES border. In the central part of the enamel band, a relatively weakly folded zone (TZ) is observed, providing the transition of the first type into the second type of enamel. The most different in terms of measurement and structure are found in the remains of the species from the Myrne site, having thick IPM in the first and third types (Tab. 1, Textfigs 3,4 ), as well as the non-wave-like (decussated) structure of the $\mathrm{TZ}$ zone.

\section{Equus caballus, konik polski, Roztocze National Park, recent, $P 3$}

Radial enamel, as with other forms, has two dominant types - the first and the second. Next to the EDJ border, there is a third type of enamel, clearly visible, especially on the metaconid. (Tabs 1, 2, Text-figs 3, 4, 7a, e). The enamel of the first type is presented with a clear IPM matrix of linear structure, between which there are layers of PE hydroxyapatite prisms, slightly inclined towards the EDJ limits (Text-fig. 7c, e). In the transition zone (TZ), enamel of the first type passes into enamel of the second type in a wave (Text-fig. 7a, c).

The second type has very tightly arranged prisms in an ellipse-like and simultaneously horseshoe-like tuft. The rows of IPM matrix are less developed (Text-fig. 7c, f). The arrangement of the prisms and prisms of the IPM matrix from the EDJ border to the OES border entirely resembles a fan-like structure with sparse decussations (Text-fig. 7c, d). Progressive strengthening of the PE hydroxyapatite prism rows and reduction of the share of IPM structures towards the OES boundary are also observed (Text-fig. 7a), which is also appropriate for other forms of this "tarpan" group. The thickness of the IPM rows in type I is $1.65 \mu \mathrm{m}$ on average, and in PE prisms $1.33 \mu \mathrm{m}$. The exceptions of morphology include the fact that the PE hydroxyapatite prisms and the IPM matrix prisms are inclined in different directions: the first, towards the EDJ, the second, towards the OES (Textfig. 7b, c). Such a structure was also noted by Koenigswald (1980), and this structure yields additional mechanical hardness of the enamel and a more qualitative effect of the process of its functioning.

\section{Equus przewalskii, Przewalski's horse, Chornobyl Exclu- sion Zone, recent, $M 1$}

The enamel of the upper roots belongs to three types. The first type occupies almost $70 \%$ of the width of the enamel. It is composed of parallel rows of IPM and prisms (PE), which are of equal thickness (Tabs 1, 2, Text-figs 3, 4, 8a, d), and the prisms are inclined towards the OES at an angle of 

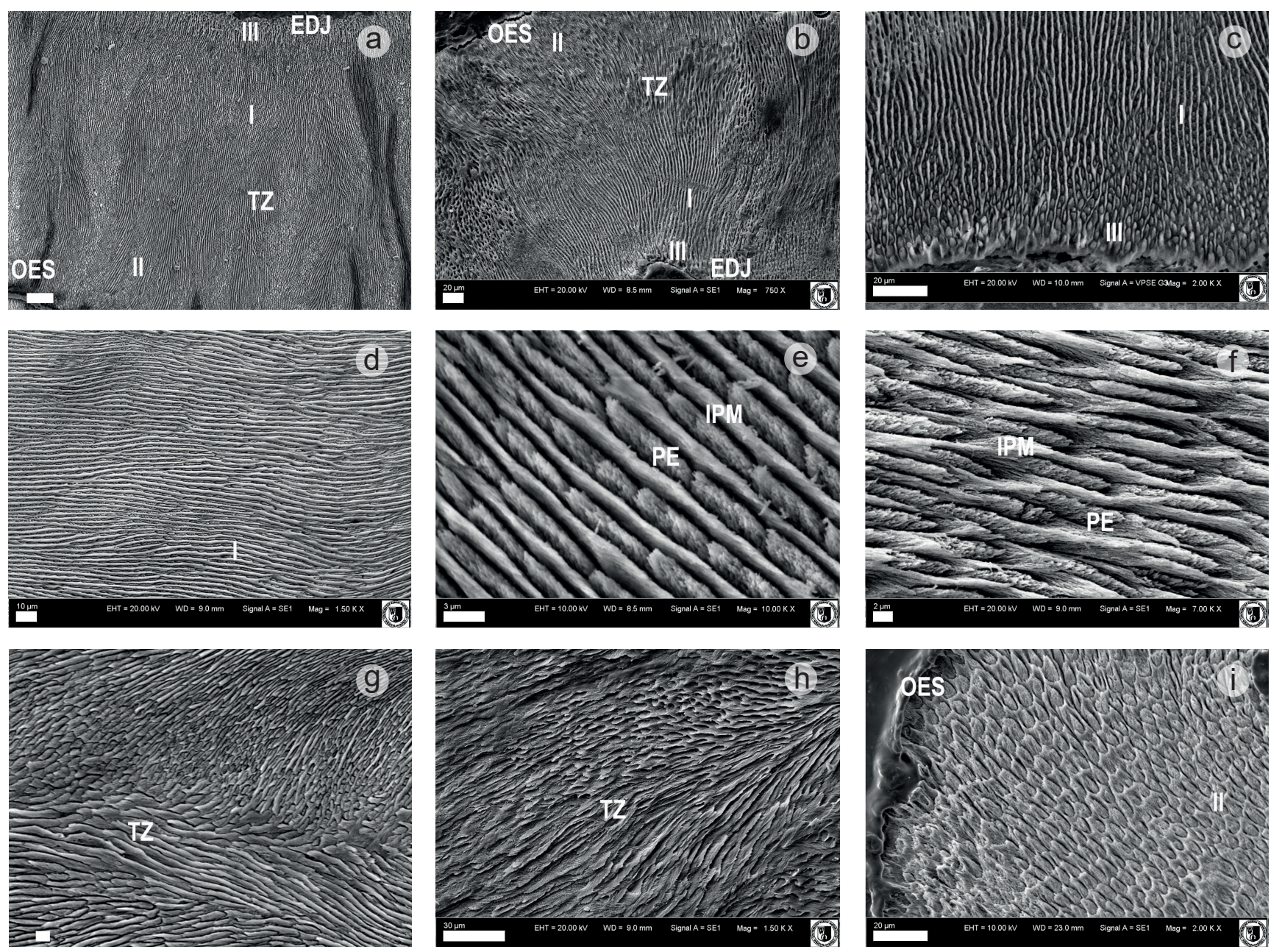

Text-fig. 8. Enamel ultrastructure of M1, Equus przewalskii (Chornobyl Exclusion Zone). a, b: enamel row, scale bar $=100$ and 20 $\mu \mathrm{m}$ respectively; c: type I and III, scale bar $=20 \mu \mathrm{m}$; $d-f$ : first type enamel arrangement, scale bar $d=10, e=3 \mu \mathrm{m}$ and $\mathrm{f}=\mathbf{2} \mu \mathrm{m}$; $\mathrm{g}$, h: prisms of TZ, scale bar $=\mathbf{5 0}$ and $30 \mu \mathrm{m}$ respectively; i: type II near OES, scale bar $=20 \mu \mathrm{m}$.

almost $25^{\circ}$ and enclosed in slightly elongated bundles (Textfig. $8 \mathrm{c}, \mathrm{d}, \mathrm{e})$. The beams of the prisms become more inclined towards the OES and elongated in the first (Text-fig. 8e) and the second (Text-fig. 8i) types. The peculiarity of their arrangement is that in the transition zone, (TZ) individual beams of prisms are shrouded in IPM structures, and the structure of the enamel layer resembles a grid (Text-fig. 8f).

The structures of the IPM are fine-grained and markedly inclined (almost $30^{\circ}$ ) to the OES border, where they take the horseshoe-shape characteristic of the second type of enamel (Text-fig. 8b, i). The transition zone (TZ) of the first and second types of enamel is clearly wavy in structure, and often resembles HSB (Text-fig. 8b, g, h). There are wedge-shaped mutual occurrences of enamel types I and II (Text-fig. 8a, b, $\mathrm{g}$ ), which is a feature not observed in other species. In some cases, the slope of the beams to the OES is significant, and consequently they resemble fairly elongated structures in the IPM, filled with small crystals (Text-fig. 8b, f).

The third type of enamel near the EDJ border is seen sporadically, rather weakly, or may be completely absent (Text-fig. 8b, c). The enamel of the lower molars of the species has a similar structure to the upper teeth, includes three types (I, II, III) of enamel, has a slight wave in the transition from type I to type II and a more noticeable development of the third type of enamel (Text-fig. 8b).

\section{Equus hydruntinus, Kabazi 2 locality, M1-2}

Both upper and lower molars of this species had a wide and well-developed strip of enamel around the perimeter of the teeth, which is an indicator of the antiquity of the species compared to the others. Between the boundaries of OES and EDJ, enamel can be divided into 3 equal parts: near EDJ, enamel of the first type; near OES, of the second type; and between them, a relatively wide transition zone. Each of these parts occupies about $30 \%$ of the thickness (width) of the enamel, and has its own characteristics (Tab. 1, Textfigs $3,4,9$ ). For example, enamel of the first type has well developed (wide) strips of IPM (their width is on average $1.93 \mu \mathrm{m}$ ), which are concluded strictly in parallel with each other (Text-fig. 9a). Accordingly, the strips of prisms of hydroxyapatite $\mathrm{PE}$ are quite thin and poorly developed (their width is on average $0.78 \mu \mathrm{m}$ ), and their prisms are poorly enclosed in bundles.

In the transition zone, $\mathrm{TZ}$, which is relatively wide, the enamel of the first type gradually and in a slightly wavy way transitions to enamel of the second type, with a gradual increase in the width of the beams of the prism PE. Accordingly, the width of the series of IPM (up to $0.59 \mu \mathrm{m}$ ) is the lowest among the comparative forms. Towards the boundary of the OES, the prisms gradually increase their 

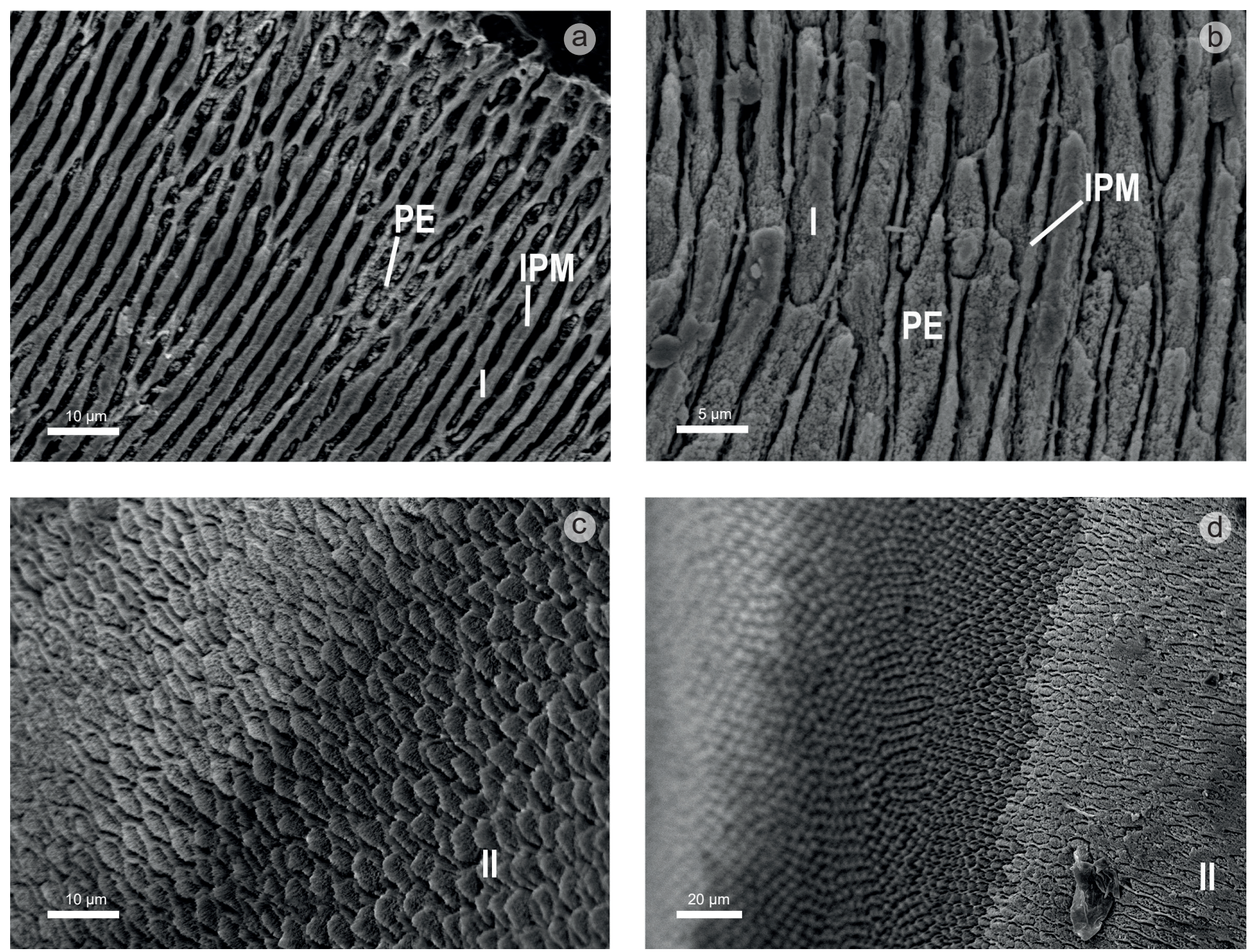

Text-fig. 9. Enamel ultrastructure of M1-2, Equus hydruntinus (Kabazi 2). a, b: type I; c, d: type II.

inclination (up to about $40^{\circ}$ ), and take the form of fairly elongated structures (Text-fig. 9b). A thread of poorly developed enamel of the second type is observed near the boundary of the OES (Text-fig. 9c). Its indicator is that it has relatively noticeable and relatively well-developed bands of IPM prisms compared to other forms, as well as an unusual (leaf-like) shape of PE prisms, which are rounded and different from their cross-section (Text-fig. 9d).

The structure of Equus hydruntinus molar enamel differs in the following ways from other forms of small horses of the "tarpan" group: almost no enamel of the third type, weak development of enamel of the second type, relatively wide transition zone TZ with an easy wave structure of IPM, and wide and parallel rows of IPM in enamel of the first type. Such features of morphology in the structure of the enamel distinguish this species from other comparative forms and confirm the data on its phylogenetic isolation (Bennett et al. 2017). These and other features were given particular attention in the comparative analysis of tooth enamel of horses and donkeys (Easley 1998, Kempson et al. 2003, Du Toit et al. 2008).

\section{Incisor enamel - incisors}

To begin with, we note that for horses, the structure of incisor enamel has not been studied in as much detail as the masticatory teeth (Muylle et al. 2001, Luszczynski and
Pieszka 2011). The data currently available concern the dependence of incisor enamel structure on their function, environment, food and phytoliths (Erickson 2014). The morphology of the incisor enamel in the forms studied demonstrates the similarity as well as the difference, and testifies to its specificity as a functional feature. A common feature of the enamel of the incisors is its HSB-like structure, which is clearly visible in the longitudinal section of the incisors in almost all mammals (Wahlert and Koenigswald 1985, Kalthoff 2000, Koenigswald 2011, Luszczynski and Pieszka 2011, Schrock et al. 2013). Less clearly, the same HSB structure is traced on the cross-section (horizontal) of the incisors. It is established that the enamel ultrastructure of the upper and lower cutters is similar in both their vertical and their horizontal sections.

Enamel of the longitudinal (vertical) section of the tarpan incisors (Text-fig. 10) has a similar HSB structure in Equus gmelini forms from different localities we studied. The rows of radial enamel are composed of individual prisms, which are enclosed in bundles. They are arranged alternately almost vertically or almost horizontally and create a ladderlike HSB structure inclined at an angle to the EDJ boundary. This structure (next to EDJ) was referred to by us as portio interna (= IPI according to Wahlert and Koenigswald 1985). Layer of weakly intertwined rows of tangential enamel are noted next to the OES boundary (Text-fig. 10). According 

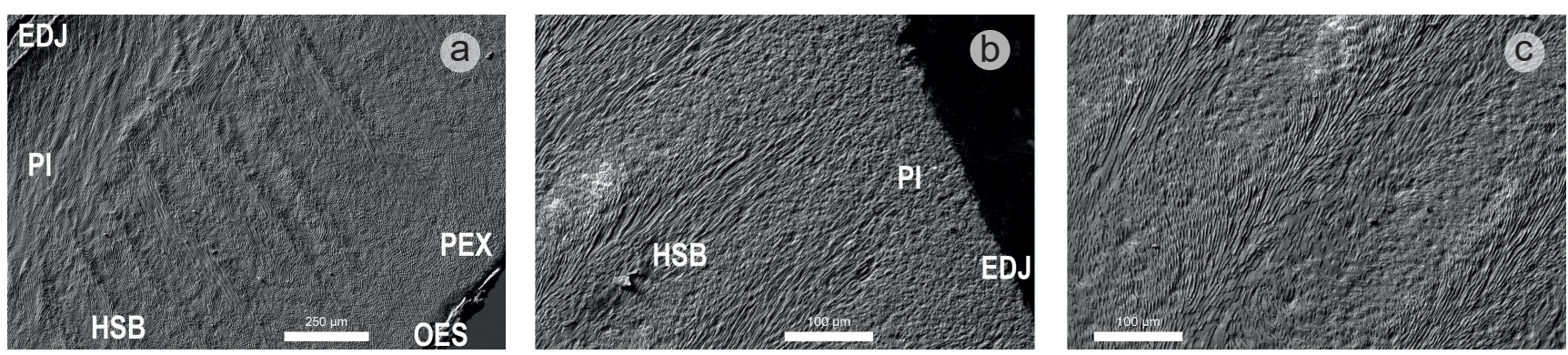

Text-fig. 10. Enamel ultrastructure of I1 (a) and I2 (b, c), Equus gmelini, tarpan (Myrne). a: vertical section; b, c: horizontal cross-section, scale bar $=250$ and $100 \mu \mathrm{m}$ respectively.
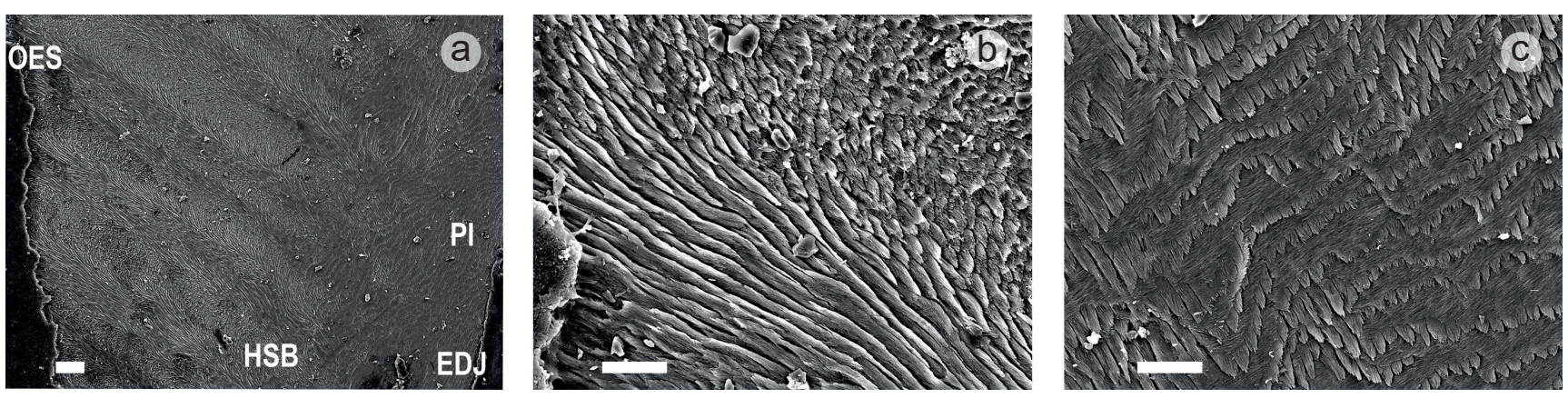

Text-fig. 11. Enamel ultrastructure of first (a) and second (b, c) lower incisors, Equus caballus (konik polski), vertical sections. a: enamel row, scale bar $=100 \mu \mathrm{m}$; b: arranging the prisms in the HSB structure, scale bar $=20 \mu \mathrm{m}$; : arranging the prisms in PI structure, scale bar $=20 \mu \mathrm{m}$.
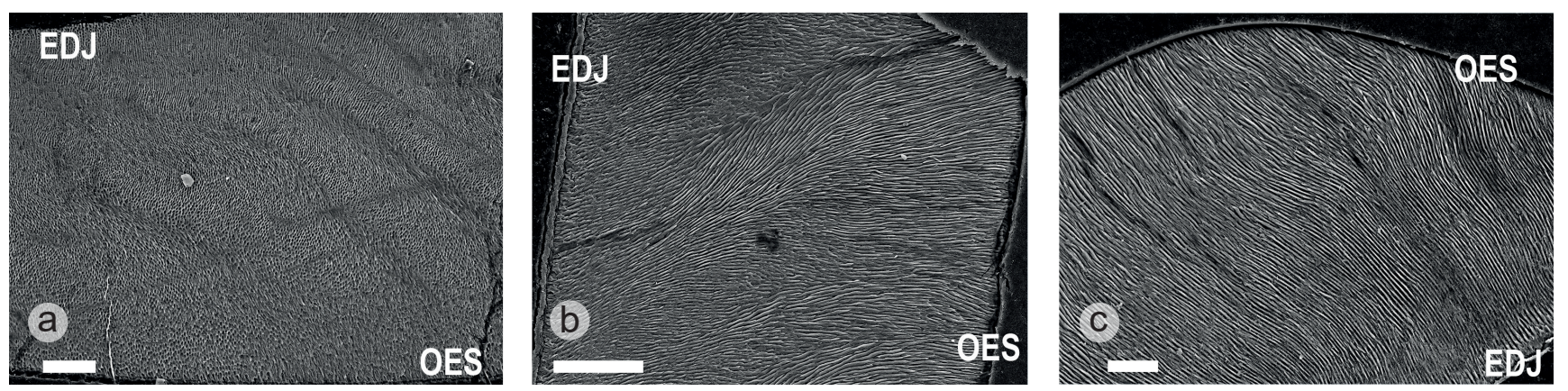

Text-fig. 12. HSB of first and second upper incisors of Equus przewalskii (Chornobyl Exclusion Zone). a, b: vertical section, scale bar $=\mathbf{1 0 0} \mu \mathrm{m}$; c: horizontal cross-section, scale bar $=\mathbf{5 0} \mu \mathrm{m}$.

to our division, this is the portio externa layer, PEX (= PE according to Wahlert and Koenigswald 1985). In the middle part of the enamel, the prisms are arranged in HSB structures (= OPI according to Wahlert and Koenigswald 1985), which are the essential part of the structure of the incisors. In crosssection, the enamel structure also has the shape of HSB, which is found in konik polski incisor enamel with a fairly clear vertical or horizontal arrangement of prisms in rows.

In the konik polski lower incisor (Text-fig. 11) the vertical section of the incisor characterizes the enamel as an HSBlike structure. They are composed of consecutively arranged IPM rows and prisms that are arranged appropriately at an angle of almost $90^{\circ}$ (tilted opposite) (Text-fig. 11b, c). They are inclined to the vertical axis of the tooth at an angle of up to $40-45^{\circ}$. This structure in the arrangement of the prisms and their rows (bands) creates the HSB structure, located next to the boundaries of the OES, and this can even be observed by the naked eye.

Between the HSB type glaze and the EDJ boundary, there is a relatively wide zone with no clearly defined boundaries with the HSB. This zone is dominated by tangential enamel, where the intertwining of vertical and horizontal prism systems is clearly visible (Text-fig. 11a). In the crosssection between the boundaries of EDJ and OES, the enamel resembles wavy HSB bands of parallel rows of prisms of the IPM matrix and PE prisms. (Text-fig. 11c).

In Przewalski's horse, Equus przewalskii, and its upper (Text-fig. 12) and lower incisors, the enamel of the incisors between the EDJ and OES boundaries shows a wavy banded structure. This can be characterized as HSB-uniserial with consecutive rows of prisms and IPM (Text-fig. 12a, b). Parallel rows of IPM structures consist of small prisms, which are clearly thicker than the prisms rows - PE.

In the vertical cross-section, the enamel demonstrates an arrangement of HSB structures similar to other forms of the "tarpan" group, with the difference that in E. przewalskii, such bands are clearly separated by borders and are wedgeshaped (Text-fig. 12b), just as they are on molars.

IPM structures, unlike prismatic structures, are often arranged almost horizontally. They are shown in elongated 

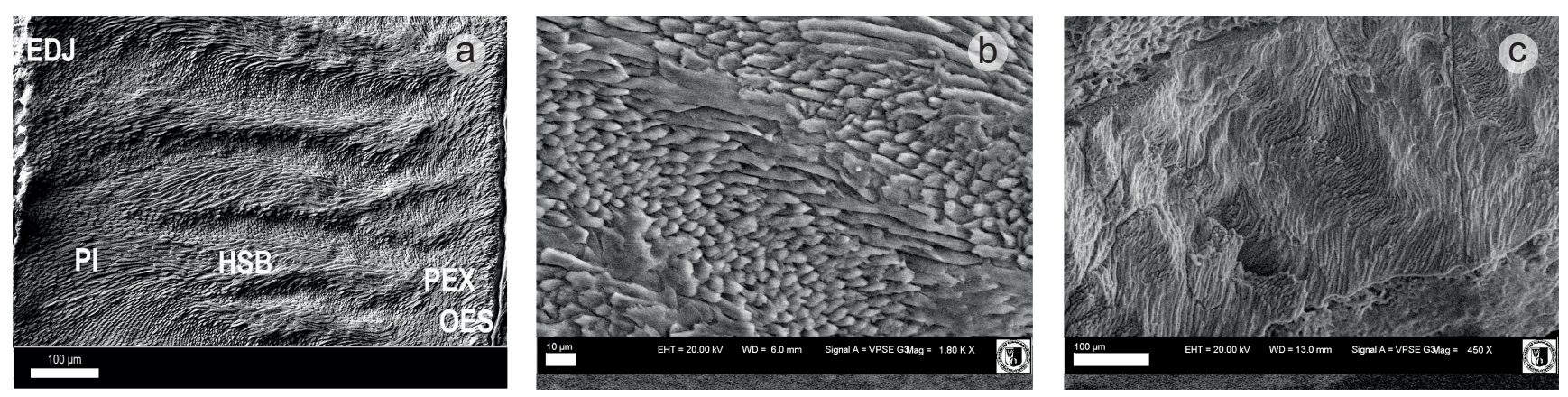

Text-fig. 13. Enamel ultrastructure of I1, Equus hydruntinus (Kabazi 2). a: vertical sections, scale bar = $100 \mu$ m; b: horizontal and vertical arrangement of prisms in the HSB structure, scale bar $=10 \mu \mathrm{m}$; c: unstructured PLEX enamel at the end of the root, scale bar $=\mathbf{1 0 0} \mu \mathrm{m}$.

and almost uninterrupted rows with possible distortions (Text-fig. 12c).

In Equus hydruntinus and its upper incisors (Textfig. 13), the enamel of the incisors, as in other comparative forms, has an HSB-like structure with pronounced alternate rows of prism at the height of the teeth, which eventually resembles a ladder structure of enamel (Text-fig. 13a). Prisms are placed vertically or horizontally, which makes the differences between the individual rows and forms the structure of the enamel ladder (Text-fig. 13b).

Although the transition between rows is gradual, it also shows clear boundaries between vertical and horizontal rows, which are always inclined towards the EDJ boundary. Near this boundary, they lose that row structure and form a special layer of radial enamel, the prisms of which are arranged linearly (Text-fig. 13a) or slightly wavy and inclined towards the root of the tooth. The enamel prisms of this layer are grouped into oval or elongated beams between which there are no structures of the IPM type.

At the boundary of the OES of prisms of the HSB type, the ladder structures do not form any special layer (Textfig. 13a). In the upper (cutting) part of the incisor rows, the HSB are relatively narrow and delicate. At the same time, closer to the top of the root, they become thicker and rarer. This structure of the enamel has its own peculiarities associated with the function of cutting (grazing) plants. The exception to the enamel structure of the incisors of this type is the presence of unstructured PLEX type enamel on the inner (lingual) part of the incisors, which is relatively rare (Text-fig. 13). As a rule, the enamel of the lingual and labial surface of the incisors does not differ in structure.

\section{Comparison and discussion}

Currently, the morphology of teeth and the structure of their enamel in horses is relatively well known, thanks to the research of previous authors (Kilic et al. 1997a, Muylle et. al. 2001, Dixon and Dacre 2005, Du Toit et al. 2008, Ramzan etal. 2010). Their work has concerned the morphology of various types of radial enamel, its taxonomic specificity, principles of functioning, pathology and treatment options, chemical composition, isotopes, etc. Our study complements this information with results of comparative analyses on several forms not yet properly investigated. The characteristics of tooth enamel morphology in small horses of the "tarpan" group allow us to identify common features characteristic of tarpans from Myrne, Kamiana Mohyla and Hirzhevo, as well as the konik polski from Roztocze NP and Przewalski's horse from the CEZ. Materials of the morphologically close but phylogenetically somewhat distant species of European ass were used as a point of comparison. These types of comparative forms are characterized by three types of radial enamel (I, II, III according to Kilic et al. 1997a), and a similar percentage in the formation of enamel stripes on the periphery and on the conids of the teeth (Tab. 1). Enamel of the first type (up to $50 \%$ ) predominates, slightly less of the second is found, and the third type does not exceed 5-7\% in enamel structure, or may even be absent as, for example, in Equus hydruntinus. For the first time, the presence of a transition zone (interzone - TZ) between the first and second types of enamel, which is located in the middle part of the enamel row between the boundaries of EDJ and OES, was isolated and described. This and similar features of the enamel structure were also noted in other article (Du Toit et al. 2008), but without the enamel of the transition zone.

In the evolution of the enamel of the root teeth of the forms studied, there is a general trend visible, in which the proportion of the first type of enamel increases from $35 \%$ to $75 \%$ alongside a corresponding decrease in the proportion of the second type of enamel. This conclusion is confirmed by the data on the relative thickness (roughness) of the IPM series and the prism of hydroxyapatite PE collected in bundles. The ratio of their thickness indicates a gradual (over time) decrease in the thickness of the rows of the IPM matrix and an increase in the weight (width) of the beams of hydroxyapatite prisms (Tab. 1). This is especially evident in the second type of enamel. Closer to the OES boundary, the rows of the IPM matrix become quite thin and make up only $10 \%$ of the total thickness of the prisms and IPM. The beams of PE hydroxyapatite crystals predominate here, with these always being placed at a certain angle near the OES boundary.

The layering prisms of hydroxyapatite PE in bundles also carries these features, and is directed from beams that are almost equilateral or round to beams that are rectangular and extended (Text-fig. 3). This trend persists not only in geological time, but also in the direction of transition from the first type of enamel to the second in the TZ, i.e., from the EDJ boundary to the OES boundary. This is associated with a gradual increase in the angle of the prisms from an almost vertical to almost horizontal position, which is especially evident in Przewalski's horse and the European wild ass. This 
allows us to estimate with certain assumptions that in the forms studied, this angle is approximately $20^{\circ}$, except for the form from the Kamiana Mohyla where it is almost $45^{\circ}$, where the prisms are very inclined and placed almost horizontally. (Text-figs 8f, 9b). The angle of inclination of the prism beams relative to the vertical axis of the tooth is somewhat dependent on the height of the tooth, and characterizes the shape of the prism beams in cross-section. In the first type of enamel, this shape is usually rectangular and slightly elongated, and in the second type it is hoof-like or elongated (more than twice the length), which is observed from the middle of the transition zone (TZ) to the OES boundary.

One indicator of particular importance is the mutual conclusion of the prisms and IPM in the TZ, which is generally wavy in nature. This zone of vortex or decussation distinguishes the studied representatives from each other. For example, in the konik polski, the type of prism is dotted (Text-fig. 7d), in Myrne it is X-shaped or interlaced (Textfig. 4a), in the Kamiana Mohyla and Hirzhevo forms it is wavy (Text-fig. 6c), and in Przewalski's horse it is HSBshaped and wedge-shaped (Text-fig. 8b, g, h). In European wild ass, this transition of the first and second types of enamel has a rather weak and slightly wavy character of IPM and PE (Text-fig. 9b).

In the enamel of the first type, there are the widest rows of IPM structures, which are thicker than the rows of prisms, and these are observed in the tarpan from Myrne. An almost equal width of IPM and prisms can be discerned in the tarpan from Kamiana Mohyla. In the form of the tarpan from Hirzhevo and in konik polski, IPM is clearly thinner than the rows of prisms. In Przewalski's horse, the IPM rows are usually thinner, but in rare cases there are parallel IPM rows and PE prisms. For comparison, we note that in the form of Equus hydruntinus from Kabazi 2, rows of IPM prisms are quite thick, which is typical for the first type of enamel of older forms, such as tarpan from Myrne, and the rows of hydroxyapatite prisms are noticeably thinner.

These data (along with others) can be a good indicator of the geological age of remains and sites, ranging from Kabazi 2 (Late Pleistocene) to modern forms. According to these indicators of geological age, the forms studied can be placed in the following sequence: Kabazi 2 - Late Pleistocene, Myrne - Kamiana Mohyla - Hirzhevo as successive stages of the early Holocene and modern forms - konik polski and Przewalski's horse. Moreover, tarpan, especially from the locality of Hirzhevo, and konik polski show the greatest morphological similarity in the structure of the enamel of the first type (Tab.1, Text-figs 2, 3). The shape of the prism bundles (PE) is rectangular and slightly elongated, which indicates a slight angle of inclination (up to $20^{\circ}$ ) to the vertical axis of the tooth.

The second type of enamel (Myrne and Kamiana Mohyla forms) has a relatively elongated horseshoe-like shape in the groups of PE prisms, which means that they are significantly inclined towards the plane of the chewing surface of the tooth. In the forms from Hirzhevo and the konik polski, these clusters are short and horseshoe-like, i.e., arranged more perpendicularly along the tooth height. The second type of enamel indicates the similarity of the structure in the konik polski and the Przewalski's horse, especially in the morphology of IPM. On this basis, the separation of the European wild ass from the comparison groups is obvious, as is confirmed by other data (Bennett et al. 2017). The tarpan has low PE and IPM values, which brings it somewhat closer to the ass.

Enamel of the third type possesses some special characteristics. It is always located near the EDJ border. This is a small row (5-7\% of the total width of the enamel), mostly chaotically stacked prisms of PE, which may appear sporadically, not in a continuous series and are separated, as a rule, by rather thin rows of IPM (Dixon 2002, Englisch et al. 2017). This type is differently represented in the forms studied except Equus hydruntinus, where this type of enamel is almost absent. The morphology and functional role of the third type of enamel is not as significant in relation to the other types.

The European wild ass differs most clearly from the comparative forms by rather thick rows of the IPM matrix, weak wavy enamel of the first and second type in the transition zone (TZ), and the absence of the third type of enamel on the root teeth. On this basis, the tarpan, the konik polski and the Przewalski's horse form one group (cluster),
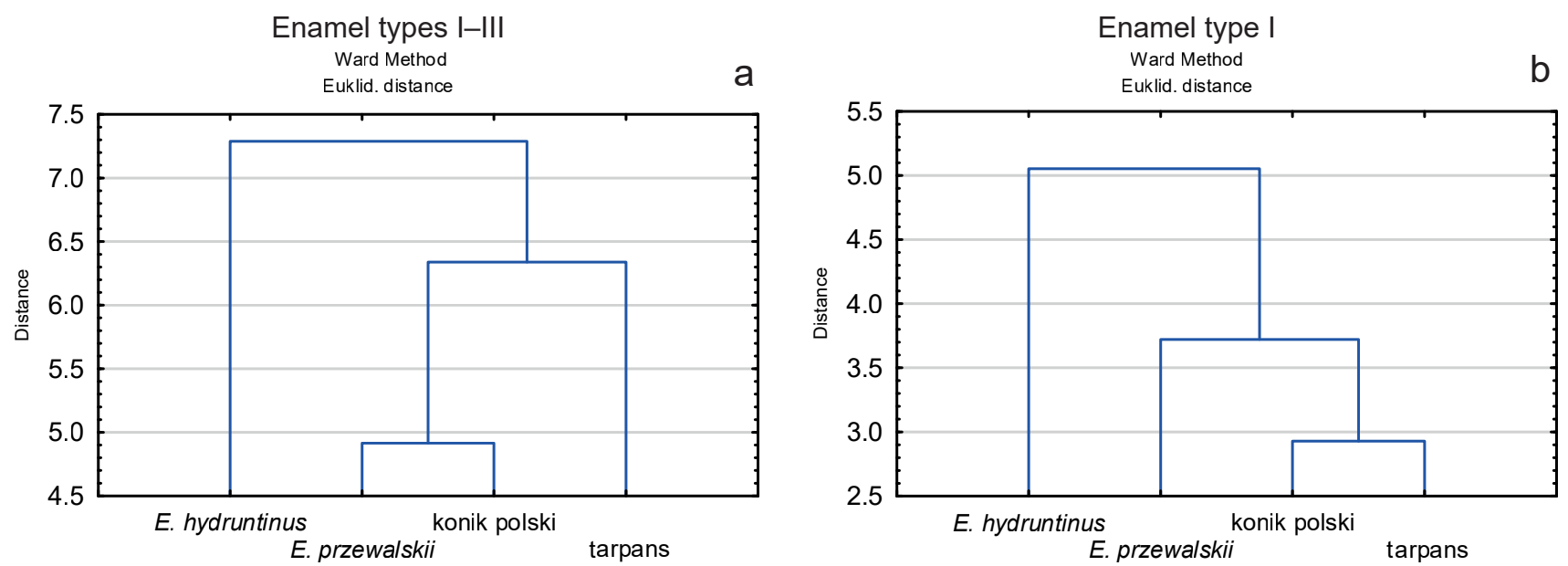

Text-fig. 14. Dendrograms of studied taxa based on enamel ultrastructure characters. a: dendrogram based on all three enamel types; b: dendrogram based on enamel type $I$. 
and are clearly distinguished from the European wild ass (Text-fig. 14). Przewalski's horse has a slightly different structure of enamel, which has a rather poorly developed enamel of the third type. In addition, they have a fairly pronounced wedge-shaped decussation of prisms and IPM in the TZ and a larger angle of inclination of the prisms near the OES boundary.

Based on the experiments conducted and analyses, it has been established that the basic trends in the evolution of enamel in small forms of the "tarpan" group are the strengthening of the first and second types of enamel due to the progressive geological time of increasing the thickness of PE prism bundles and reducing the thickness of IPM. Another direction is the increasingly complicated (up to decussation) nature of the wavelength of the prisms in the TZ. An important functional tendency is seen in the strengthening of the HSB type enamel structure in the incisors. The incisor enamel accepts a significant functional load with the function of grazing on mostly dry grasses with phytoliths and sand grains, which causes an increased effect of abrasion of their enamel, while strengthening its structure behind the HSB type. This lamellar type enamel is evolutionarily the most advanced structure and one that has been relatively well studied in rodents performing similar functions (Kalthoff 2000, Koenigswald et al. 2011). In contrast to the incisors, the functional role of enamel in chewing/molar teeth is more diverse and complicated by the mechanical movements of the chewing process itself (Jordana et al. 2014). This causes some differences in the structure of the enamel in the various taxa examined, to some extent also dependent on the nature of the food. For example, the tarpan steppe form and the European wild ass as representatives of consumers of dry food have a welldeveloped HSB structure, and the PE prisms are arranged in well-formed bundles. On the other hand, konik polski and Przewalski's horse are adapted to softer plant food with possibly less structurally reinforced enamel. The outer border of tooth enamel, OES, is important because it must protect the enamel (along with the cement) on the side of the teeth as opposed to the EDJ border on the dentin side.

\section{Conclusions}

Based on the morphology of the enamel that has been characterized here, it can be concluded that among the forms of the tarpan group, the forms from Myrne and Kamiana Mohyla are the most morphologically close to each other. Another similarity is seen in the forms from Hirzhevo and the konik polski. Przewalski's horse is somewhat separate. The morphology of their tooth enamel is similar to other forms, but differs in the clinker structure of the enamel in the TZ, medium prisms, and rows of prisms and IPMs that are almost equal in width. The Equus hydruntinus species turned out to be the most distinctive among the forms examined, with thick rows of IPM, the almost total absence of the third enamel type and, a very poor wavy structure of the transition zone (Text-fig. 14).

The peculiarities of the enamel structure in the forms examined are expressed in the table and the relevant statistical calculation diagram, which indicate the similarities and morphological difference. The species Equus hydruntinus is quite remote from other comparable forms. Przewalski's horse together with konik polski and tarpans form one cluster, and at the same time it differs morphologically from them (Text-fig. 14). On the other hand, the species Equus hydruntinus as presented by Orlando et al. (2006, 2008 ) showed that it is a more monolithic group of equines hydruntinus-hemionus and at the same time differs from the "caballus" group and the "quagga" group. Similar results are also presented in the work of Vilstrup (Vilstrup et. al. 2013) where the "hemionus-hydruntinus" group also constitutes a separate clade.

\section{Acknowledgements}

This work was supported by the International Visegrad Fund [52010462].

The authors appreciate the reviewers and editor valuable and profound comments.

\section{References}

Bennett, E. A., Champlot, S., Peters, J., Arbuckle, B. S., Guimaraes, S., Pruvost, M., Bar-David, S., Davis, S. J. M., Gautier, M., Kaczensky, P., Kuehn, R., Mashkour, M., Morales-Muñiz, A., Pucher, E., Tournepiche, J. F., Uerpmann, H. P., Bălăşescu, A., Germonpré, M., Gündem, C. Y., Hemami, M. R., Moullé, P. E., Ötzan, A., Uerpmann, M., Walzer, C., Grange, T., Geigl, E. M. (2017): Taming the late Quaternary phylogeography of the Eurasiatic wild ass through ancient and modern DNA. - PLoS ONE, 12: 1-28.

https://doi.org/10.1371/journal.pone.0174216

Bibikova, V. I. (1972): Ostatki subfossilnovo tarpana na Ukraine [Subfossil tarpan remains in Ukraine]. Byulleten' Moskovskoho obshchestva ispytateley prirody, otdel biologii [Bulletin of Moscow Society of Naturalists, Biology Department], 48: 97-114. (in Russian)

Bibikova, V. I., Belan, N. G. (1979): Lokal'nye varianty i gruppirovki pozdnepaleoliticheskogo teriokompleksa Yugo-Vostochnoy Evropy [Local variants and groupings of the Late Paleolithic therio-complex of South-Eastern Europe]. - Byulleten' Moskovskoho obshchestva ispytateley prirody, otdel biologii [Bulletin of Moscow Society of Naturalists, Biology Department], 84: 3-14. (in Russian)

Bibikova, V. I., Belan, N. G. (1981): Rannegolotsenoviy tarpan na territorii Severo-Zapadnogo Prichernomorya [Early Holocene tarpan in the northwestern Black Sea region]. - Vestnik zoologii [Bulletin of Zoology], 3: 2126. (in Russian)

Bibikova, V. I., Belan, N. G. (1984): Tarpan epokhi mezolita Severnogo Prichernomor'ya [Mesolithic Tarpan of the Northern Black Sea Region]. - In: Telegin, D. Ya. (ed.), Materialy kamennogo veka na territorii Ukrainy [Materials of the Stone Age on the territory of Ukraine]. Naukova dumka [Scientific opinion], Kyiv, pp. 73-75. (in Russian)

Boyde, A. (1964): The structure and development of mammalian enamel; Doctoral dissertation. - MS, Faculty of 
Medicine, University of London, London, 298 pp. + $68 \mathrm{pp}$. with different pagination. (copy available on-line)

Burke, A., Eisenmann, V., Ambler, G. K. (2003): The systematic position of Equus hydruntinus, an extinct species of Pleistocene equid. - Quaternary Research, 59: 459-469. https://doi.org/10.1016/S0033-5894(03)00059-0

Chabai, V. P., Monigal, K., Marks, A. E. (eds) (2004): The Middle Paleolithic and Early Upper Paleolithic of Eastern Crimea. - ERAUL, 104: 25-35.

Cieslak, J., Wodas, L., Borowska, A., Cothran, E. G., Khanshour, A. M., Mackowski, M. (2017): Characterization of the Polish Primitive Horse (Konik) maternal lines using mitochondrial D-loop sequence variation. - PeerJ, 5: e3714 (17 pp.).

https://doi.org/10.7717/peerj.3714

Conti, N., Petronio, C., Salari, L. (2010): The Late Pleistocene Equids from "Tana delle Iene" (Ceglie Messapica, Brindisi, Southern Italy). - Bollettino della Società Paleontologica Italiana, 49(2): 227-236.

Croitor, R. (2018): Middle age horses from the western borders of Khazar Khaganate (saltovo-mayaki culture of eastern Ukraine). - Journal of Historical Archaeology and Anthropological Sciences, 3: 706-713. https://doi.org/10.15406/jhaas.2018.03.00154

Cucchi, T., Mohaseb, A., Peigné, S., Debue, K., Orlando, L., Mashkour, M. (2017): Detecting taxonomic and phylogenetic signals in equid cheek teeth: towards new palaeontological and archaeological proxies. - Royal Society Open Science, 4: 160997 (14 pp.). https://doi.org/10.1098/rsos.160997

Demeshkant, V. (2019): Strukturalno-funkcjonalna charakterystyka szkliwa zębów koni grupy „Tarpan” [Structural and functional characteristics of tooth enamel of the “Tarpan” horses' group]. - In: Mazurska hodowla koników polskich - przeszłość, teraźniejszość i pryszłość [Masurian horse breeding - past, present and future], September $5^{\text {th }}-7^{\text {th }} 2019$, Popielno - Wierzba, Poland, p. 42. (in Polish)

Dixon, P. (2002): The gross, histological, and ultrastructural anatomy of equine teeth and their relationship to disease. - The American Association of Equine Practitioners, 48: 421-437.

Dixon, P. M, Dacre, I. (2005): A review of equine dental disorders. - Veterinary Journal, 169(2): 165-187. https://doi.org/10.1016/j.tvj1.2004.03.022

Du Toit, N., Kempson, S. A., Dixon, P. M. (2008): Donkey dental anatomy. Part 1: Gross and computed axial tomography examinations. - The Veterinary Journal, 176(3): 338-344.

https://doi.org/10.1016/j.tvj1.2008.03.003

Easley, J. (1998): Dental care and instrumentation. - Veterinary Clinics of North America: Equine Practice, 14: 309-332. https://doi.org/10.1016/S0749-0739(17)30200-6

Englisch, L. M., Kostrzewa, K., Kopke, S., Failing, K., Staszyk, C. (2017): Uneven distribution of enamel, dentine and cementum in cheek teeth of domestic horses (Equus caballus): A micro computed tomography study. - PLoS ONE, 12: 1-14.

https://doi.org/10.1371/journal.pone.0183220
Erickson, K. L. (2014) Prairie grass phytolith hardness and the evolution of ungulate hypsodonty. - Historical Biology, 26(6): 737-744. https://doi.org/10.1080/08912963.2013.841155

Fornal, A., Kowalska, K., Zabek, T., Piestrzynska-Kajtoch, A., Musiał, A., Ropka-Molik, K. (2020): Genetic Diversity and population structure of Polish konik horse based on individuals from all the male founder lines and microsatellite markers. - Animals, 10(9): 1569 (11 pp.). https://doi.org/10.3390/ani10091569

Forsten, A. (1988): Middle Pleistocene replacement of stenonid horses by caballoid horses - ecological implications. - Palaeogeography, Palaeoclimatology, Palaeoecology, 65(1-2): 23-33. https://doi.org/10.1016/0031-0182(88)90109-5

Frątczak, M., Małysz, P., Dybczyńska, M., \& Wnuk-Pawlak, E. (2020): Powstanie i hodowla krajowa rasy konik polski [Establishment and domestic breeding of the konik polski breed]. Wybrane zagadnienia produkcji zwierzęcej, 15. (in Polish).

Gaunitz, C., Fages, A., Hanghøj, K., Albrechtsen, A., Khan, N., Schubert, M. et al. (2018): Ancient genomes revisit the ancestry of domestic and Przewalski's horses. - Science, 360(6384): 111-114.

https://doi.org/10.1126/science.aao3297

Gladenko, V. K. (1976): Belorusskaya loshad' [Belarus Horse]. - Uradzhay, Minsk, 108 pp. (in Russian)

Greenfield, H., Moore, N., Steppan, K. (2015). Estimating the age- and season-of-death for wild equids: a comparison of techniques utilising a sample from the Late Neolithic site of Bad Buchau-Dullenried, Germany. - Open Quaternary, 1: Art. 3 (28 pp.).

https://doi.org/10.5334/oq.ac

Gromova, W. (1949): Istoriya loshadey (roda Equus) v Starom Svete [History of horses (genus Equus) in the Old World]. - Trudy Paleontologitcheskogo instituta Akademii Nauk SSSR [Proceedings of Paleontological Institute of the USSR Academy of Sciences], 17: 1-373. (in Russian)

Jansen, T., Forster, P., Levine, M. A., Oelke, H., Hurles, M., Renfrew, C., Weber, J., Olek, K. (2002): Mitochondrial DNA and the origins of the domestic horse. - Proceedings of the National Academy of Sciences of the United States of America, 99(16): 10905-10910.

https://doi.org/10.1073/pnas.152330099

Jaworska, J., Jaworski, Z., McDonnell, S. M., Górecka-Bruzda, A. (2020): Harem stallion changes are not associated with diminished reproductive performance of females in semi-feral Konik polski horses (Equus caballus). Theriogenology, 151: 1-6. https://doi.org/10.1016/j.theriogenology.2020.03.033

Jordana, X., Marín-Moratalla, N., Moncunill-Solé, B., Köhler, M. (2014): Ecological and life-history correlates of enamel growth in ruminants (Artiodactyla). - Biological Journal of the Linnean Society, 112(4): 657-667. https://doi.org/10.1111/bij.12264

Kalthoff, D. C. (2000): Die Schmelzmikrostruktur in den Incisiven der hamsterartigen Nagetiere und anderer Myomorpha (Rodentia, Mammalia). - Palaeontographica, Abt. A, 259(1-6): 1-193.

Kaminski, S., Hering, D. M., Jaworski, Z., Zabolewicz, T., Rusc, A. (2017): Assessment of genomic inbreeding 
in Polish Konik horses. - Polish Journal of Veterinary Sciences, 20(3): 603-605.

https://doi.org/10.1515/pjvs-2017-0074

Kempson, A., Davidson, M. E., Dacre, I. T. (2003): Surface types of rasps on the occlusal the effect of three equine: a scanning electron microscopic study. - Journal of Veterinary Dentistry, 20: 19-27.

https://doi.org/10.1177/089875640302000102

Kilic, S., Dixon, P. M., Kempson, S. A. (1997a): A light microscopic and ultrastructural examination of calcified dental tissues of horses: 1. The occlusal surface and enamel thickness. - Equine Veterinary Journal, 29(3): 190-197. https://doi.org/10.1111/j.2042-3306.1997.tb01668.x

Kilic, S., Dixon, P. M., Kempson, S. A. (1997b): A light microscopic and ultrastructural examination of calcified dental tissues of horses: 3. Dentine. - Equine Veterinary Journal, 29(3): 206-212. https://doi.org/10.1111/j.2042-3306.1997.tb01670.x

Koenigswald, W. v. (1980): Schmelzmuster und Morphologie in den Molaren der Arvicolidae (Rodentia). - Abhandlungen der Senckenbergischen Naturforschenden Gesellschaft, 539(1): 1-129.

Koenigswald, W. v. (2011): Diversity of hypsodont teeth in mammalian dentitions - construction and classification. - Palaeontographica, Abt. A, 294(1-3): 63-94. https://doi.org/10.1127/pala/294/2011/63

Koenigswald, W. v., Martin, T., Pfretzschner, H. U. (1993): Phylogenetic interpretation of enamel structures in mammalian teeth - possibilities and problems. - In: Szalay, F. S., Novacek, M. J., McKenna, M. C. (eds), Mammal Phylogeny, Placentals. Springer, New York, pp. 303-314. https://doi.org/10.1007/978-1-4613-9246-0_21

Kosintsev, P. A. (2015): Kostnye ostatki iz poseleniya Belkaragay I [Bone remains from the settlement of Belkaragai I]. - In: Beisenov, A. Z. (ed.), Drevniy Turgay i Velikaya Step': chast' i tseloe [Ancient Turgai and the great steppe: part and whole]. Institut arkheologii im. A. Kh. Margulana, Kostanay, Almaty, pp 142-144. (in Russian)

Kosintsev, P. A., Bachura, O. P. (2013): Late Pleistocene and Holocene mammal fauna of the Southern Urals. - Quaternary International, 284: 161-170. https://doi.org/10.1016/j.quaint.2012.06.022

Kuzmina, I. E. (1997): Loshadi Severnoy Evrazii ot pliotsena do sovremennosti [Horses of North Eurasia from the Pliocene to the present time]. - Trudy Zoologicheskogo instituta Rossiyskoy Akademii Nauk, [Zoological Proceedings Institute of RAS], 273: 1-223. (in Russian)

Kvist, L., Niskanen, M. (2020): Modern northern domestic horses carry mitochondrial DNA similar to Przewalski's horse. - Journal of Mammalian Evolution, 28: 371-376. https://doi.org/10.1007/s10914-020-09517-6

Levine, M. A. (1999): Botai and the origins of horse domestication. - Journal of Anthropological Archaeology, 18(1): 29-78.

https://doi.org/10.1006/jaar.1998.0332

Lewis, A. J., Sreekumar, C., Srikant, N., Boaz, K., Nandita, K. P., Manaktala, N., Yellapurkar, S. (2021): Estimation of age by evaluating the occlusal tooth wear in molars: A study on Dakshina Kannada population. - Clinical, Cosmetic and Investigational Dentistry, 13: 429-440. https://doi.org/10.2147/CCIDE.S313587
Luszczynski, J., Pieszka, M. (2011): The effect of year and season of birth, sex, sire, and breeder on ossification of the distal epiphyseal cartilage of the radial bone in Thoroughbred horses. - Turkish Journal of Veterinary and Animal Sciences, 35(6): 413-420.

Markova, A. K. (2005): Small Mammals from the Paleolithic Site of Kabazi II, Western Crimea. - In: Chabai, V., Richter, J., Uthmeier, T. (eds), Kabazi II: Last Interglacial Occupation, Environment \& Subsistence (Paleolithic Sites of Crimea, Vol. 1). National Academy of Sciences of Ukraine, Institute of Archaeology, Crimena Branch, Simferopol; University of Cologne, Institute of Prehistoric Archaeology, Cologne, pp. 51-65.

Martin, T. (2000): Enamel microstructure. - In: Singer, R. (ed.), Encyclopedia of Paleontology. Dearborn, Chicago, pp. 403-409.

Muylle, S., Simoens, P., Lauwers, H. (2001): The distribution of intratubular dentine in equine incisors: a scanning electron microscopic study. - Equine Veterinary Journal, 33: 65-9. https://doi.org/10.2746/042516401776767395

Orlando, L., Male, D., Alberdi, M. T., Prado, J. L., Prieto, A., Cooper, A., Hänni, C. (2008): Ancient DNA clarifies the evolutionary history of American Late Pleistocene equids. - Journal of Molecular Evolution, 66: 533-538. https://doi.org/10.1007/s00239-008-9100-x

Orlando, L., Mashkour, M., Burke, A., Douady, C. J., Eisenmann, V., Hänni, C. (2006): Geographic distribution of an extinct equid (Equus hydruntinus: Mammalia, Equidae) revealed by morphological and genetical analyses of fossils. - Molecular Ecology, 15: 2083-2093. https://doi.org/10.1111/j.1365-294X.2006.02922.x

Orlando, L., Metcalf, J. L., Alberdi, M. T., Telles-Antunes, M., Bonjean, D., Otte, M., Martin, F., Eisenmann, V., Mashkour, M., Morello, F., Prado, J. L., Salas-Gismondi, R., Shockey, B. J., Wrinn, P. J., Vasil'ev, S. K., Ovodov, N. D., Cherry, M. I., Hopood, B., Male, D., Austin, J. J., Hänni, C., Cooper, A. (2009): Revising the recent evolutionary history of equids using ancient DNA. - Proceedings of the National Academy of Sciences of the United States of America 106: 21754-21759. https://doi.org/10.1073/pnas.0903672106

Pasicka, E. (2013): Polish Konik horse-characteristics and historical background of native descendants of tarpan. - Acta Scientiarum Polonorum Medicina Veterinaria, 12: 25-38.

Ramzan, P. H. L., Dixon, P. M., Kempson, S. A., Rossdale, P. D. (2010): Dental dysplasia and oligodontia in a Thoroughbred colt. - Equine Veterinary Journal, 33: 99-104. https://doi.org/10.2746/042516401776767511

Sapozhnikov, V., Sapozhnikova, V. (2011): Kamennyy vek Severo-Zapadnogo Prichernomor'ya [Stone Age of the Northwestern Black Sea region]. - Stratum plus: Archaeology and Cultural Anthropology, Saint Petersburg, pp. 15-141 (in Russian)

Schindelin, J., Rueden, C. T., Hiner, M. C., Eliceiri, K. W. (2015): The ImageJ ecosystem: An open platform for biomedical image analysis. - Molecular Reproduction and Development, 82(7-8): 518-29. https://doi.org/10.1002/mrd.22489

Schrock, P., Lüpke, M., Seifert, H., Staszyk, C. (2013): Three-dimensional anatomy of equine incisors: Tooth 
length, enamel cover and age related changes. - BMC Veterinary Research, 9: 249 (9 pp.).

https://doi.org/10.1186/1746-6148-9-249

Schulz, E., Kaiser, T. M. (2013): Historical distribution, habitat requirements and feeding ecology of the genus Equus (Perissodactyla). - Mammal Review, 43: 111-123. https://doi.org/10.1111/j.1365-2907.2012.00210.x

Seetah, K., Cardini, A., Barker, G. (2016): A 'long-fuse domestication' of the horse? Tooth shape suggests explosive change in modern breeds compared with extinct populations and living Przewalski's horses. - Holocene, 26: $1326-13$. https://doi.org/10.1177/0959683616638436

Siemieniuch, M., Jaworski, Z. (2019): Próby użytkowości koników polskich - wpływ na kształtowanie rasy [Test of utilities of the Polish konik horses - an impact on the breed formation]. - In: Mazurska hodowla koników polskich - przeszłość, teraźniejszość i pryszłość [Masurian horse breeding - past, present and future], September $5^{\text {th }}-7^{\text {th }} 2019$, Popielno - Wierzba, Poland, pp. 30-33. (in Polish)

Slivinska, K., Klich, D., Yasynetska, N. (2019): Parasitological survey of wild Przewalski's horses (Equus ferus przewalskii, Poliakov, 1881) in the Chernobyl Exclusion Zone, Ukraine during 2014-2018: influence of year, season, age, sex and group size of horses. - In: Mazurska hodowla koników polskich - przeszłość, teraźniejszość i pryszłość [Masurian horse breeding - past, present and future], September $5^{\text {th }}-7^{\text {th }} 2019$, Popielno - Wierzba, Poland, p. 28.

Spassov, N., Iliev, N. (1998): The Late Pleistocene and Holocene wild horses of East Europe and the polyphyleth- ic origin of the domestic horse. - In: Stefanovich, M., Todorova, H., Hauptmann, H. (eds), James H. Gaul in memoriam. The James Harvey Gaul Fondation, Sofia, pp. 371-389.

Spindler, L., Comeskey, D., Chabai, V., Uthmeier, T., Buckley, M., Devièse, T., Higham, T. (2021): Dating the last Middle Palaeolithic of the Crimean Peninsula: New hydroxyproline AMS dates from the site of Kabazi II. Journal of Human Evolution, 156: 102996 (10 pp.). https://doi.org/10.1016/j.jhevol.2021.102996

Steiner, C. C., Makova, K. D., Ryder, O. A. (2013): Mitochondrial genome: Clues about the evolution of extant equids and genomic diversity of horse breeds. - In: Chowdhary, B. P. (ed.), Equine Genomics. John Wiley \& Sons, Hoboken, pp. 311-321. https://doi.org/10.1002/9781118522158.ch19

Taylor, W. T. T., Barrón-Ortiz, C. I. (2021): Rethinking the evidence for early horse domestication at Botai. - Scientific Reports, 11: 7440 (11 pp.). https://doi.org/10.1038/s41598-021-86832-9

Vetulani, T. (1928): Tarpan und polnisches Landpferd (Konik). - Biologia Generalis, 4: 387-402.

Vilstrup, J. T., Seguin-Orlando, A., Stiller, M., Ginolhac, A., Raghavan, M., Nielsen, S. C. A., Weinstock, J., Froese, D., Vasiliev, S. K., Ovodov, N. D., Clary, J., Helgen, K. M., Fleischer, R. C., Cooper, A., Shapiro, B., Orlando, L. (2013): Mitochondrial phylogenomics of modern and ancient equids. - PLoS ONE, 8: e55950 (12 pp.). https://doi.org/10.1371/journal.pone.0055950

Wahlert, J. H., Koenigswald, W. v. (1985): Specialized enamel in incisors of eomyid rodents. - American Museum Novitates, 2832: 1-11. 